\title{
The impact of speciated VOCs on regional ozone increment derived from measurements at the UK EMEP supersites between 1999 and 2012
}

\author{
C. S. Malley ${ }^{1,2}$, C. F. Braban ${ }^{1}$, P. Dumitrean ${ }^{3}$, J. N. Cape ${ }^{1}$, and M. R. Heal ${ }^{2}$ \\ ${ }^{1}$ NERC Centre for Ecology \& Hydrology, Edinburgh, UK \\ ${ }^{2}$ School of Chemistry, University of Edinburgh, Edinburgh, UK \\ ${ }^{3}$ Ricardo-AEA, Didcot, UK \\ Correspondence to: C. S. Malley (c.malley@ sms.ed.ac.uk)
}

Received: 21 January 2015 - Published in Atmos. Chem. Phys. Discuss.: 10 March 2015

Revised: 2 July 2015 - Accepted: 15 July 2015 - Published: 28 July 2015

\begin{abstract}
The impact of 27 volatile organic compounds (VOCs) on the regional $\mathrm{O}_{3}$ increment was investigated using measurements made at the UK EMEP supersites Harwell (1999-2001 and 2010-2012) and Auchencorth (2012). Ozone at these sites is representative of rural $\mathrm{O}_{3}$ in southeast England and northern UK, respectively. The monthlydiurnal regional $\mathrm{O}_{3}$ increment was defined as the difference between the regional and hemispheric background $\mathrm{O}_{3}$ concentrations, respectively, derived from oxidant vs. $\mathrm{NO}_{x}$ correlation plots, and cluster analysis of back trajectories arriving at Mace Head, Ireland. At Harwell, which had substantially greater regional $\mathrm{O}_{3}$ increments than Auchencorth, variation in the regional $\mathrm{O}_{3}$ increment mirrored afternoon depletion of anthropogenic VOCs due to photochemistry (after accounting for diurnal changes in boundary layer mixing depth, and weighting VOC concentrations according to their photochemical ozone creation potential). A positive regional $\mathrm{O}_{3}$ increment occurred consistently during the summer, during which time afternoon photochemical depletion was calculated for the majority of measured VOCs, and to the greatest extent for ethene and $m+p$-xylene. This indicates that, of the measured VOCs, ethene and $\mathrm{m}+\mathrm{p}$-xylene emissions reduction would be most effective in reducing the regional $\mathrm{O}_{3}$ increment but that reductions in a larger number of VOCs would be required for further improvement.

The VOC diurnal photochemical depletion was linked to anthropogenic sources of the VOC emissions through the integration of gridded anthropogenic VOC emission estimates over $96 \mathrm{~h}$ air-mass back trajectories. This demonstrated that one factor limiting the effectiveness of VOC gridded emis-
\end{abstract}

sions for use in measurement and modelling studies is the highly aggregated nature of the 11 SNAP (Selected Nomenclature for Air Pollution) source sectors in which they are reported, as monthly variation in speciated VOC trajectory emissions did not reflect monthly changes in individual VOC diurnal photochemical depletion. Additionally, the major VOC emission source sectors during elevated regional $\mathrm{O}_{3}$ increment at Harwell were more narrowly defined through disaggregation of the SNAP emissions to 91 NFR (Nomenclature for Reporting) codes (i.e. sectors 3D2 (domestic solvent use), 3D3 (other product use) and 2D2 (food and drink)). However, spatial variation in the contribution of NFR sectors to parent SNAP emissions could only be accounted for at the country level. Hence, the future reporting of gridded VOC emissions in source sectors more highly disaggregated than currently (e.g. to NFR codes) would facilitate a more precise identification of those VOC sources most important for mitigation of the impact of VOCs on $\mathrm{O}_{3}$ formation.

In summary, this work presents a clear methodology for achieving a coherent $\mathrm{VOC}$, regional- $\mathrm{O}_{3}$-impact chemical climate using measurement data and explores the effect of limited emission and measurement species on the understanding of the regional VOC contribution to $\mathrm{O}_{3}$ concentrations. 


\section{Introduction}

Production of ground-level ozone $\left(\mathrm{O}_{3}\right)$ is dependent on concentrations of $\mathrm{NO}_{x}\left(\mathrm{NO}\right.$ and $\left.\mathrm{NO}_{2}\right)$, methane, carbon monoxide, and volatile organic compounds (VOCs) (Jenkin and Clemitshaw, 2000). The formation of $\mathrm{O}_{3}$ causes substantial deleterious human health and environmental impacts worldwide (RoTAP; 2012; REVIHAAP, 2013). Development of policies for the mitigation of these impacts requires understanding of the influences on $\mathrm{O}_{3}$ concentrations from local, regional and hemispheric-scale processes. The range in VOC atmospheric lifetimes from a few hours to several days (Atkinson, 2000) means that the major fraction of the VOC impact on $\mathrm{O}_{3}$ production occurs on the regional scale of airmass movements. At the regional scale, Gauss et al. (2014) modelled the reductions in $\mathrm{O}_{3}$ impact across Europe on human health (using the SOMO35 metric) and vegetation (using the deciduous forest $\mathrm{POD}_{Y}$ metric) resulting from $15 \%$ reductions in anthropogenic $\mathrm{NO}_{x}$ and $\mathrm{VOC}$ emissions across the $\mathrm{EU}$ and showed that VOC emission reductions were more effective than $\mathrm{NO}_{x}$ emission reductions in reducing the $\mathrm{O}_{3}$ impact metrics across much of north-west Europe. Hence, knowledge of the contribution of individual VOCs to $\mathrm{O}_{3}$ production on the European (regional) scale will enable targeting of the most effective VOC reductions for reducing regionally derived $\mathrm{O}_{3}$ exposure relevant to $\mathrm{O}_{3}$ impacts.

Within Europe, the European Monitoring and Evaluation Programme (EMEP) makes in situ atmospheric composition measurements at sites considered to have minimal influence from local emission sources (Tørseth et al., 2012). The UK operates two EMEP Level II monitoring sites (or "supersites"), Auchencorth and Harwell, at which hourly concentrations of $\mathrm{O}_{3}, \mathrm{NO}_{x}$ and 27 VOCs are measured. In this work, chemical climates (defined in Malley et al., 2014a) are derived to quantify the impact of the measured VOCs on the regional increment of $\mathrm{O}_{3}$ concentrations (the difference between regional background and hemispheric background $\mathrm{O}_{3}$ concentrations) measured at Harwell and Auchencorth. Full definitions of each of these $\mathrm{O}_{3}$ quantities are given in Sect. 2.1. Monthly-diurnal $\mathrm{O}_{3}$ variation at the EMEP supersites has previously been shown to be representative of wider geographical areas, namely rural background air of southeast England and northern UK for the Harwell and Auchencorth UK supersites, respectively (Malley et al., 2014b).

The interpretation of VOC measurements at rural sites has previously been undertaken using positive matrix factorisation (PMF) (Lanz et al., 2009), trajectory analysis (Sauvage et al., 2009), VOC variability as a measure of source proximity (Jobson et al., 1999), winter/summer VOC ratios to indicate changing emission sources (Jobson et al., 1999), and the ratio of VOCs with similar reactivity to highlight changes in emission sources (Yates et al., 2010). These studies identified VOC emission sources based on measured VOC concentrations. However, the "state" of atmospheric composition variation producing a regional $\mathrm{O}_{3}$ increment above hemispheric background concentrations is more rigorously evaluated by considering the chemical loss of the measured VOCs, since it is the VOC chemical loss in the air mass that drives the production of a regional $\mathrm{O}_{3}$ increment, not the VOC concentration remaining in the air mass. In urban environments, the chemical loss of VOCs has been calculated through the estimation of initial emission ratios of two VOCs and calculation of photochemical age through parameters such as " $\mathrm{OH}$ exposure" or "VOC consumption" (Shao et al., 2009; Yuan et al., 2012). This method is not appropriate for rural studies since it assumes that local sources dominate emissions.

In this work, monthly-averaged diurnal variations of individual VOC concentrations relative to ethane were used to assess the photochemical loss of each VOC and its contribution to the regional $\mathrm{O}_{3}$ increment at Harwell and Auchencorth. Monthly-diurnal averaging was chosen as the annual and daily cycles are key features of $\mathrm{O}_{3}$ variability associated with the driving processes on its concentrations and on its impact. For example, the monthly and diurnal variation in $\mathrm{O}_{3}$ is central to determining the extent and spatiotemporal trends in health- and vegetation-relevant $\mathrm{O}_{3}$ metrics (Malley et al., 2015). Ozone variability at hundreds of monitoring sites globally has also been characterised based on monthly-diurnal variation (Tarasova et al., 2007). Monthlydiurnal averaging was therefore also appropriate for setting this work in the wider context, especially given the relative scarcity of hourly VOC measurements. The magnitude of VOC chemical loss at each site was linked to anthropogenic emissions by estimating the integrated VOC emissions along $96 \mathrm{~h}$ air-mass back trajectories. These emissions, from the 11 Selected Nomenclature for Air Pollution (SNAP; EEA, 2013) source sectors, were speciated to compare observed VOC variation with an estimate of individual VOC integrated back-trajectory emissions. Integration of emissions, VOC chemistry and $\mathrm{O}_{3}$ production has been reported previously for one location in the UK using a photochemical trajectory model with a near-explicit chemical mechanism for a large suite of VOCs (Derwent et al., 2007a, b). The advantage of the methodology presented here, based on measurement data, is that uncertainties associated with the speciation of VOC emission source categories can be identified. A country-specific disaggregation of emissions into 91 more narrowly defined Nomenclature for Reporting (NFR; EEA, 2013) source sectors was used to determine more precisely the activities contributing to VOC back-trajectory emissions estimates. This current work presents a clear methodology for achieving a coherent VOC, regional- $\mathrm{O}_{3}$-impact chemical climate and explores the effect of limited emission and measurement species on the understanding of the regional contribution to $\mathrm{O}_{3}$ concentrations. 


\section{Methodology}

This work was undertaken by applying the chemical climatology framework outlined in Malley et al. (2014a). A chemical climate is derived through the linkage of a specific "impact" of atmospheric composition (here, regional $\mathrm{O}_{3}$ increment) through the "state" of relevant atmospheric composition variation (VOC diurnal photochemical depletion) to its causal "drivers" (meteorology and emissions). The aim of this framework is to provide a consistent method for both consideration of impact severity and the conditions producing it, hence highlighting pathways for mitigation. The Methods and Results sections are subdivided into impact (Sects. 2.1 and 3.1 for Methods and Results, respectively), state (Sects. 2.2, 3.2) and drivers (Sects. 2.3, 3.3) to emphasise the analyses used to derive the components of the chemical climate. Analyses were undertaken for the periods 1999-2001 and 2010-2012 at Harwell and 2010-2012 at Auchencorth. Measured data were obtained from UK-AIR (http://uk-air.defra.gov.uk/) and EMEP (http://ebas.nilu.no/). For each year, the monthly-averaged diurnal cycles of each atmospheric component were calculated, i.e. $24 \times 12=288$ values per year.

\subsection{Regional $\mathrm{O}_{3}$ increment impact}

The regional $\mathrm{O}_{3}$ increment is defined as the regional background $\mathrm{O}_{3}$ concentrations minus the hemispheric background $\mathrm{O}_{3}$ concentration. Here, regional background $\mathrm{O}_{3}$ concentration is defined as that which is imported into a local spatial domain following modification of hemispheric background $\mathrm{O}_{3}$ concentrations by European emissions. Examples of local spatial domains are south-east England and northern $\mathrm{UK}$ for which, based on monthly-diurnal $\mathrm{O}_{3}$ variation, Harwell and Auchencorth, respectively, were shown previously to be representative (Malley et al., 2014b). The hemispheric background $\mathrm{O}_{3}$ concentration is in turn defined as that which is imported into the European domain, with minimal influence from European emissions.

Hemispheric background $\mathrm{O}_{3}$ concentrations were derived by applying Ward's method of hierarchical cluster analysis to pre-calculated $96 \mathrm{~h}$ air-mass back trajectories arriving at $3 \mathrm{~h}$ intervals at Mace Head, Ireland (R Core Development Team, 2008; Carslaw and Ropkins, 2012; Draxler and Rolph, 2013), to identify periods with no European influence. The discrimination achieved by cluster analysis may be influenced by user choices but the method used here was shown to be the most accurate of commonly used clustering techniques (Mangiameli et al., 1996). In Ward's method, each object (back trajectory) initially constitutes its own cluster. The algorithm then calculates which two clusters, when merged, give the smallest increase in total within-cluster variance. The process is repeated until all trajectories are located in one cluster (Kaufman and Rousseeuw, 1990). The dendrogram summarising the cluster merging process is then "cut" at an appropriate level to produce the cluster set. The aim is to maximise explained inter-trajectory variability using a small number of clusters to highlight major distinctions between trajectory paths. The distance between a trajectory and its cluster mean was quantified using the two-dimensional "angle" of each trajectory (or cluster mean trajectory) from the origin (i.e. the supersite) at common time points along the trajectory:

$d_{1,2}=\frac{1}{n} \sum_{i=1}^{n} \cos ^{-1}\left(0.5 \frac{A_{i}+B_{i}+C_{i}}{\sqrt{A_{i} B_{i}}}\right)$,

where

$$
\begin{aligned}
& A_{i}=\left(X_{1}(i)-X_{0}\right)^{2}+\left(Y_{1}(i)-Y_{0}\right)^{2}, \\
& B_{i}=\left(X_{2}(i)-X_{0}\right)^{2}+\left(Y_{2}(i)-Y_{0}\right)^{2}, \\
& C_{i}=\left(X_{2}(i)-X_{1}(i)\right)^{2}+\left(Y_{2}(i)-Y_{1}(i)\right)^{2} .
\end{aligned}
$$

$d_{1,2}$ is the distance between trajectory 1 and trajectory 2 , $X_{0}, Y_{0}$ are the latitude and longitude coordinates of the origin of the trajectory, and $X_{1}(i), Y_{1}(i)$, and $X_{2}(i), Y_{2}(i)$ are the coordinates at time $i$ of trajectories 1 and 2 , respectively. The 2920 back trajectories arriving at Mace Head each year were separated into four clusters. The monthly-diurnal cycles of $\mathrm{O}_{3}$ concentrations for the westerly trajectory cluster were used as the estimate of hemispheric background $\mathrm{O}_{3}$. These values showed excellent agreement with the monthlyaverage hemispheric background estimates derived by Derwent et al. (2007c) using Mace $\mathrm{Head} \mathrm{O}_{3}$ data and a combination of pollutant tracers and atmospheric modelling to select "clean" air masses ( $r=0.93, p<0.001$, Fig. 1).

Regional background $\mathrm{O}_{3}$ concentrations were estimated using the method of Clapp and Jenkin (2001). In the region of south-east England characterised by the Harwell supersite nine locations, ranging from rural background to kerbside, had hourly measurements of $\mathrm{O}_{3}, \mathrm{NO}$ and $\mathrm{NO}_{2}$. The $y$ intercept of the linear fit to a total oxidant $\left(\mathrm{O}_{3}+\mathrm{NO}_{2}\right)$ vs. $\mathrm{NO}_{x}\left(\mathrm{NO}+\mathrm{NO}_{2}\right)$ plot yields the $\mathrm{NO}_{x}$-independent oxidant contribution, interpreted as the regional background $\mathrm{O}_{3}$ concentration, i.e. the contribution to $\mathrm{O}_{3}$ within south-east England from processes occurring outside south-east England. Extraction of the $y$ intercept from an oxidant vs. $\mathrm{NO}_{x}$ plot for each of the 288 "month-hour" averages yielded the monthlydiurnal cycle of regional background $\mathrm{O}_{3}$ variation in southeast England. The difference between the hemispheric background and regional background $\mathrm{O}_{3}$ concentrations provided the magnitude and direction of the regional modification to hemispheric background $\mathrm{O}_{3}$ concentration. A positive regional $\mathrm{O}_{3}$ increment indicates additional $\mathrm{O}_{3}$ formation regionally in excess of hemispheric background concentrations and vice versa.

The spatial domain for which Auchencorth is representative does not have sufficient co-located $\mathrm{NO}_{x}$ and $\mathrm{O}_{3}$ monitoring sites to derive regional background $\mathrm{O}_{3}$ concentrations 


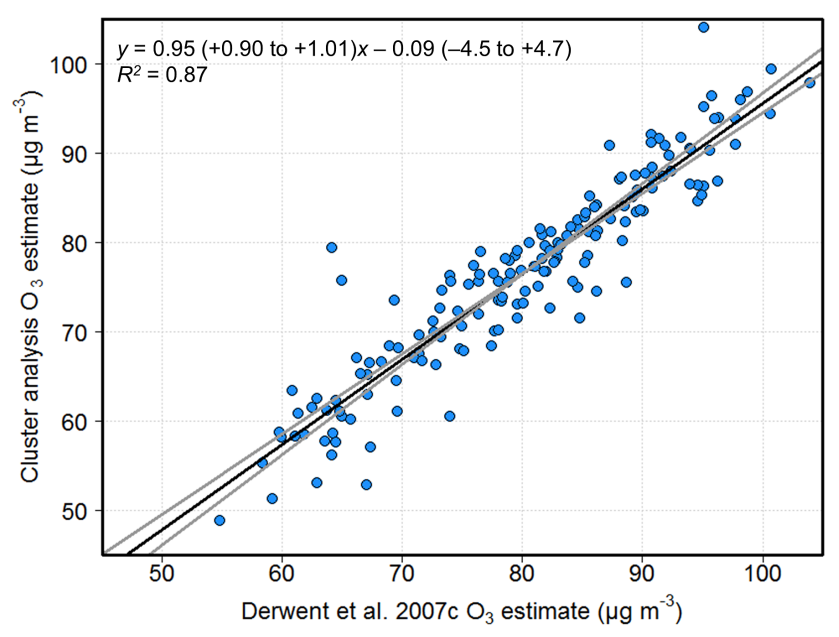

Figure 1. Correlation between monthly hemispheric background $\mathrm{O}_{3}$ concentrations derived by Derwent at al. (2007c) using pollutant tracers and atmospheric modelling to select "clean" air masses, and derived by the method described in Sect. 2.1 using cluster analysis. Black regression line is calculated by the ordinary least squares (OLS) method, with confidence intervals (95th percentile) shown in grey.

by the above method. The regional $\mathrm{O}_{3}$ increment at Auchencorth was therefore estimated by subtracting the Mace Head hemispheric background estimates directly from the Auchencorth monthly-averaged diurnal concentrations.

\subsection{State}

VOC concentrations were determined by automated gas chromatography (Dernie and Dumitrean, 2013). For 20102012, data were available for 27 species at both Harwell and Auchencorth. Concentrations of six VOCs at Auchencorth during this period were not above the reported limit of detection (LOD), so their contribution to the regional O3 increment was not evaluated. For 1999-2001, data were available for 21 VOCs at Harwell only.

The VOC data sets had extensive periods during which concentrations were below LOD, particularly at Auchencorth (e.g. between 6 and $81 \%$ below LOD at Harwell in 2011, and between 11 and $82 \%$ at Auchencorth). Therefore, maximum likelihood estimation (MLE) was used to fit three positively skewed distributions (lognormal, gamma and Weibull) to the data set for each VOC (Helsel, 2006; Gardner, 2012). The Akaike information criterion (AIC) was then used to select the distribution which best fitted the data; this provides a relative estimate of the information lost when a given distribution is used to represent a data set (Akaike, 1974). This process was performed on data for each month of the year, and separately for the 288 monthly-diurnal time periods. The fitted distributions estimated the probability that a "non-detect" (below the LOD) was a concentration in the range $0 \mu \mathrm{g} \mathrm{m}^{-3}$ to the LOD.
When non-detects occurred for all VOCs in a particular hour, these were excluded from the MLE analysis on the assumption that this was due to instrument failure. To avoid the unnecessary omission of valid concentration measurements, all other data were used, and consequently all remaining nondetects were assumed to be values below LOD. A number of non-detects due to the selective failure of the instrument to measure a particular VOC may be falsely considered to be below the LOD. However, the following evidence indicates that any bias introduced is likely to be small. Annual medians were calculated twice using MLE for Harwell in 2011, first, with the non-detects unique to each VOC, secondly with their omission (i.e. assuming all these non-detects were due to reasons other than LOD). The increase when omitted was below $10 \%$ for 11 of the 27 VOCs, including the VOCs with concentrations consistently well above the LOD. For example, the 5th percentile concentrations (of all valid concentrations) of propane, ethane and toluene were 1200 , 800 and $175 \%$ above the LOD and consequently the number of unique non-detects was relatively low (4, 2 and $1 \%$ of values, respectively). The increase when the unique nondetects were omitted was 10,8 and $3 \%$ for propane, ethane and toluene, respectively. Other VOCs had a 5 th percentile concentration much closer to the LOD, increasing the likelihood of periods during which concentrations were below LOD. For 9 of the 10 VOCs with the largest annual median increase, the 5 th percentile concentration was the LOD.

In summary, for those VOCs with few unique non-detects, the potential inclusion of non-LOD-related non-detects resulted in a small change in calculated concentration, while VOCs with a larger proportion of non-detects had concentrations more frequently close to the LOD, increasing the likelihood that the unique non-detects resulted from concentrations below the LOD. This indicates that the decision to assign all unique non-detects as values below the LOD was justified, as the potential bias introduced was small, and therefore the maximum of valid VOC concentration data was preserved and used in the MLE distribution calculations. Intraannual and monthly-diurnal variation in VOC concentrations were summarised using the monthly median concentrations and the 24 hourly median concentrations for each month from the best-fit distributions, respectively.

For each VOC, each of the 288 median monthly-diurnal concentrations was multiplied by the corresponding modelderived photochemical ozone creation potential (POCP) (Derwent et al., 2007a), to weight the observed diurnal variation of VOCs according to their different propensities for $\mathrm{O}_{3}$ formation. In Derwent et al. (2007a), a VOC POCP was defined as the ratio (multiplied by 100) of the increase in $\mathrm{O}_{3}$ due to increased emissions of the VOC simulated in a Lagrangian model along a trajectory traversing from central Europe to the $\mathrm{UK}$, relative to the modelled increase in $\mathrm{O}_{3}$ from the same mass increase in emissions of ethene (the reference POCP VOC assigned a value of 100). Multiple studies have calculated reactivity scales of $\mathrm{O}_{3}$ production poten- 
tial (OPP) for a range of VOCs using incremental reactivity methods (Luecken and Mebust, 2008; Derwent et al., 2007a; Hakami et al., 2004; Martien et al., 2003), multi-parent assignment (Bowman, 2005) and "tagging" of VOC degradation sequences (Butler et al., 2011). These varying methods were shown to be generally well correlated (Butler et al., 2011; Luecken and Mebust, 2008; Derwent et al., 2010). The Derwent et al. (2007a) POCPs are appropriate to use in this study as they were calculated under simulated north-western European conditions. Previous comparison with other VOC reactivity scales indicated uncertainty in POCP values of up to \pm 5 POCP units which equates to an average of $\pm 15 \%$ for the measured VOCs in this study (Derwent et al., 2007b).

The diurnal variation of individual VOCs due to photochemical depletion was summarised by calculating the ratio of each POCP-weighted VOC concentration to the POCPweighted ethane concentration. Ethane has the second smallest POCP of the measured VOCs, $87 \%$ smaller than the average, and $20 \%$ smaller than the next smallest POCP (benzene), so using this ratio removed the effect on diurnal VOC concentration of changes in boundary layer mixing depth. The VOC with the smallest POCP, ethyne, had low data capture at Harwell between 1999 and 2001 (maximum $57 \%$ in 2001). Additionally, ethane has a smaller rate coefficient for reaction with $\mathrm{OH}$ compared with ethyne (Table 1), and the POCPs were similar ( 7 for ethyne vs. 8 for ethane). Ratios of VOC / ethane have been used previously to estimate the photochemical loss of VOCs (Yates et al., 2010; Helmig et al., 2008; Honrath et al., 2008). It is also assumed that the diurnal variation of VOCs at the site is not driven by differences in the magnitude of VOC emissions along the trajectories contributing VOCs to that site during the day and at night. This can be verified by the similar monthly median VOC emissions emitted along the path of $96 \mathrm{~h}$ trajectories (outlined in Sect. 2.3) arriving at night (03:00) and afternoon (15:00). For example, at Harwell in 2011, night trajectory VOC emissions were no more than $\pm 12 \%$ different from afternoon. Hence, a daytime decrease in POCP-weighted VOC / ethane ratio indicates greater photochemical depletion of the VOC relative to ethane. The magnitude of diurnal photochemical variability for each VOC was derived from the difference between the average POCP-weighted VOC / ethane ratio at night (01:00-05:00) and in the afternoon (13:00-17:00). A positive value indicates daytime photochemical depletion of the VOC relative to ethane. The sum of positive daytime photochemical depletion of individual VOCs produces the total VOC diurnal photochemical depletion for each month. The monthly pattern of total VOC diurnal photochemical depletion was compared with the monthly pattern of the regional $\mathrm{O}_{3}$ increment. During those months with a positive regional $\mathrm{O}_{3}$ increment, the relative contribution of each VOC to total VOC photochemical depletion was used as an estimate of the relative contribution of each VOC to the VOC chemical loss which contributed to the production of the positive regional $\mathrm{O}_{3}$ increment.
At Auchencorth, the analysis of VOC diurnal photochemical depletion was not possible in 2010 and 2011 due to low data capture, which compromises the ability of MLE to accurately estimate median VOC concentrations. This is particularly important for ethane, as a large error in the fitted distribution for ethane propagates to all VOC / ethane ratios. In 2011 , the average proportion of non-detects for the measured VOCs was $56 \%$ when the six VOCs with no measurements above LOD were excluded (34\% for ethane). In 2012 this decreased to $34 \%$ (10\% for ethane), and VOC diurnal photochemical depletion was calculated. For comparison, at Harwell, there were on average $26 \%$ non-detects for each VOC species in 2011 ( $7 \%$ for ethane).

\subsection{Drivers}

The two main drivers producing the "state" of this chemical climate, i.e. VOC diurnal photochemical depletion, which are considered here are meteorology and anthropogenic VOC emissions. Other drivers such as biogenic VOC emissions and $\mathrm{NO}_{x}$ concentrations are drivers of the regional $\mathrm{O}_{3}$ increment. Meteorology and anthropogenic VOC emissions are the focus due to the benefits previously outlined in improvement in health- and vegetation-relevant $\mathrm{O}_{3}$ impacts that result from anthropogenic VOC emission reductions. The meteorology was characterised by monthly mean, maximum and minimum temperature, and number of hours of sunshine for Harwell and Auchencorth obtained from the UK Met Office climate summaries for "South East and Central South England" and "East Scotland", respectively (http://www. metoffice.gov.uk/climate/uk/datasets/\#) (Perry and Hollis, 2005).

To investigate geographical emission sources, the locations of each of the 96 hourly time points of the 2920 HYSPLIT $96 \mathrm{~h}$ back trajectories arriving at $3 \mathrm{~h}$ intervals per year were mapped to the $0.5^{\circ} \times 0.5^{\circ}$ gridded VOC emissions reported by EMEP and used in the EMEP model (Mareckova et al., 2013; Simpson et al., 2012). This grid encompasses the region 30.25$75.25^{\circ} \mathrm{N}, 29.75^{\circ} \mathrm{W}$ to $60.25^{\circ} \mathrm{E}$, and the emissions in each grid square are disaggregated into 11 SNAP source sectors (http://ceip.at/ms/ceip_home1/ceip_home/webdab_ emepdatabase/emissions_emepmodels/). When the location of the trajectory during a particular hour fell within the gridded domain, the annual emissions and country of the grid square over which the trajectory was located were assigned to that time point. Emissions were assigned to the country which had the greatest emissions when the grid square straddled an international border. Annual emissions were modified by prescriptive month, day-of-week and hour-of-day time factors (Simpson et al., 2012) to obtain an estimate of the hourly emissions from each SNAP sector during the hour in which the trajectory passed over the grid cell. The monthly-average hourly SNAP emission estimates at each of the $961 \mathrm{~h}$ time points were summed to give the average Euro- 
Table 1. Summary data for the measured VOCs at Auchencorth and Harwell (note that $m$-xylene and $p$-xylene are reported as a single measurement). The rate coefficients at $298 \mathrm{~K}$ for reactions of each VOC with OH are taken from Atkinson and Arey (2003), and the POCPs are from Derwent et al. (2007a). The "main source" column gives the SNAP sector with the largest contribution of that VOC to UK annual anthropogenic emissions in 2011, with the exception of isoprene which is mainly of biogenic origin (defined in Sect. 2.3). The listed SNAP sectors are SNAP 2, non-industrial combustion plants; SNAP 4, production processes; SNAP 5, extraction and distribution of fossil fuels; SNAP 6, solvent use; SNAP 7, road transport; and SNAP 8, non-road transport.

\begin{tabular}{|c|c|c|c|c|c|}
\hline VOC & Class & Chemical formula & Main source & $\begin{array}{r}\text { OH reaction rate constant } \\
\left(10^{12} \times k(298 \mathrm{~K})\right. \\
\left.\left(\mathrm{cm}^{3} \text { molecule }^{-1} \mathrm{~s}^{-1}\right)\right)\end{array}$ & $\mathrm{POCP}$ \\
\hline ethane & alkane & $\mathrm{C}_{2} \mathrm{H}_{6}$ & SNAP $5(65 \%)$ & 0.248 & 8 \\
\hline propane & alkane & $\mathrm{C}_{3} \mathrm{H}_{8}$ & SNAP $5(36 \%)$ & 1.09 & 14 \\
\hline$n$-butane & alkane & $\mathrm{C}_{4} \mathrm{H}_{10}$ & SNAP $6(44 \%)$ & 2.36 & 31 \\
\hline isobutane & alkane & $\mathrm{C}_{4} \mathrm{H}_{10}$ & SNAP $5(61 \%)$ & 2.12 & 28 \\
\hline$n$-pentane & alkane & $\mathrm{C}_{5} \mathrm{H}_{12}$ & SNAP $5(42 \%)$ & 3.80 & 40 \\
\hline isopentane & alkane & $\mathrm{C}_{5} \mathrm{H}_{12}$ & SNAP $5(41 \%)$ & 3.60 & 34 \\
\hline$n$-hexane & alkane & $\mathrm{C}_{6} \mathrm{H}_{14}$ & SNAP $6(42 \%)$ & 5.20 & 40 \\
\hline 2-methylpentane & alkane & $\mathrm{C}_{6} \mathrm{H}_{14}$ & SNAP $6(43 \%)$ & 5.20 & 41 \\
\hline$n$-heptane & alkane & $\mathrm{C}_{7} \mathrm{H}_{16}$ & SNAP $5(43 \%)$ & 6.76 & 35 \\
\hline$n$-octane & alkane & $\mathrm{C}_{8} \mathrm{H}_{18}$ & SNAP $5(64 \%)$ & 8.11 & 34 \\
\hline isooctane & alkane & $\mathrm{C}_{8} \mathrm{H}_{18}$ & SNAP $4(100 \%)$ & 3.34 & 25 \\
\hline ethene & alkene & $\mathrm{C}_{2} \mathrm{H}_{4}$ & SNAP $8(27 \%)$ & 8.52 & 100 \\
\hline propene & alkene & $\mathrm{C}_{3} \mathrm{H}_{6}$ & SNAP $4(36 \%)$ & 26.3 & 117 \\
\hline 1-butene & alkene & $\mathrm{C}_{4} \mathrm{H}_{8}$ & SNAP $7(26 \%)$ & 31.4 & 104 \\
\hline cis-2-butene & alkene & $\mathrm{C}_{4} \mathrm{H}_{8}$ & SNAP $5(87 \%)$ & 56.4 & 113 \\
\hline trans-2-butene & alkene & $\mathrm{C}_{4} \mathrm{H}_{8}$ & SNAP $5(90 \%)$ & 64.0 & 116 \\
\hline 1,3-butadiene & alkene & $\mathrm{C}_{4} \mathrm{H}_{6}$ & SNAP $8(57 \%)$ & 66.6 & 89 \\
\hline isoprene & alkene & $\mathrm{C}_{5} \mathrm{H}_{8}$ & biogenic & 100 & 114 \\
\hline ethyne & alkyne & $\mathrm{C}_{2} \mathrm{H}_{2}$ & SNAP $7(46 \%)$ & 0.78 & 7 \\
\hline benzene & aromatic & $\mathrm{C}_{6} \mathrm{H}_{6}$ & SNAP $2(35 \%)$ & 1.22 & 10 \\
\hline toluene & aromatic & $\mathrm{C}_{7} \mathrm{H}_{8}$ & SNAP $6(63 \%)$ & 5.63 & 44 \\
\hline ethylbenzene & aromatic & $\mathrm{C}_{8} \mathrm{H}_{10}$ & SNAP $6(54 \%)$ & 7.0 & 46 \\
\hline$o$-xylene & aromatic & $\mathrm{C}_{8} \mathrm{H}_{10}$ & SNAP $6(50 \%)$ & 13.6 & 78 \\
\hline$m$-xylene & aromatic & $\mathrm{C}_{8} \mathrm{H}_{10}$ & SNAP $6(71 \%)$ & 23.1 & 86 \\
\hline$p$-xylene & aromatic & $\mathrm{C}_{8} \mathrm{H}_{10}$ & SNAP $6(50 \%)$ & 14.3 & 72 \\
\hline 1,2,3-trimethylbenzene & aromatic & $\mathrm{C}_{9} \mathrm{H}_{12}$ & SNAP $6(79 \%)$ & 32.7 & 105 \\
\hline 1,2,4-trimethylbenzene & aromatic & $\mathrm{C}_{9} \mathrm{H}_{12}$ & SNAP $6(74 \%)$ & 32.5 & 110 \\
\hline 1,3,5-trimethylbenzene & aromatic & $\mathrm{C}_{9} \mathrm{H}_{12}$ & SNAP $6(71 \%)$ & 56.7 & 107 \\
\hline
\end{tabular}

pean VOC emissions estimate of all the trajectories arriving in that month (henceforth the VOC trajectory emissions estimate (TEE)) and the proportions derived from individual countries.

The total VOC TEE from the 11 SNAP sectors were speciated using the 114 VOC speciated profiles from Passant (2002) to quantify the proportion of emissions emitted as one of the 27 measured VOCs. The profiles were first applied to UK annual emissions to obtain speciated profiles for each SNAP sector which could be applied to the VOC TEEs. Each year, at the most disaggregated level, the UK National Atmospheric Emissions Inventory (NAEI) reports total VOC emissions for 337 source activities (http://naei.defra.gov.uk/data/) (Passant et al., 2013). In Passant (2002), each of these activities is assigned one of the 114 speciation profiles which in total consider the contribution from $630 \mathrm{VOCs}$, including aggregated groups of VOCs, for example "C7 alkanes".
The total annual UK emissions for each activity were apportioned between the VOCs in the assigned profile. This resulted in a matrix of 337 columns of source activities, and 630 rows of VOCs. Activities were then grouped into the 55 NFR codes used by NAEI, and then into SNAP sectors 1-9 based on the NFR-SNAP conversion recommended by the EMEP Centre for Emission Inventories and Projections (CEIP; http://www.ceip.at/fileadmin/inhalte/emep/pdf/ nfr09_to_snap.pdf). There were no reported VOC emissions from activities falling under SNAP 10 (agriculture) and SNAP 11 (other). The relative contribution of each VOC to total annual UK SNAP emissions was calculated to provide speciated emission profiles which were used to speciate the monthly SNAP sector VOC TEEs. This produced an estimate of the contribution to total monthly VOC TEE from 630 VOCs (Fig. 2). This contribution was then multiplied by 


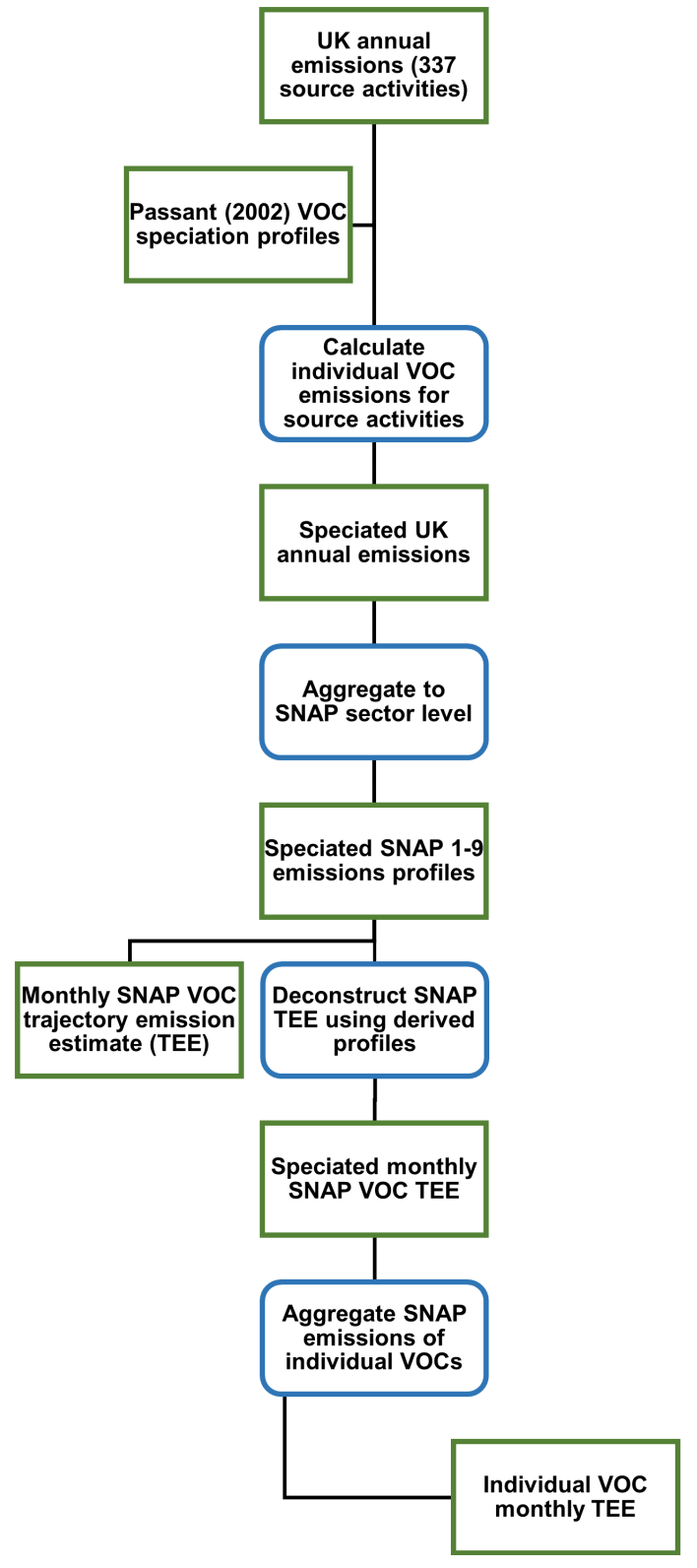

Figure 2. Flowchart demonstrating the process used to calculate the contribution of 630 individual VOCs to the monthly total VOC trajectory emissions estimate (TEE; defined in Sect. 2.3). The green rectangles represent products or data sets, and the blue rounded rectangles represent processes applied to transform a data set. Further explanation is provided in Sect. 2.3.

the VOC's POCP to weight it according to $\mathrm{O}_{3}$ formation potential.

The EU emissions inventory disaggregates annual emissions from SNAP sectors 1-9 into 91 NFR codes for each EU member state (EEA, 2014). The monthly change in the SNAP sector VOC TEE was attributed to changes in the contribution from the more narrowly defined NFR codes, based on the country-specific contributions of each NFR sector to

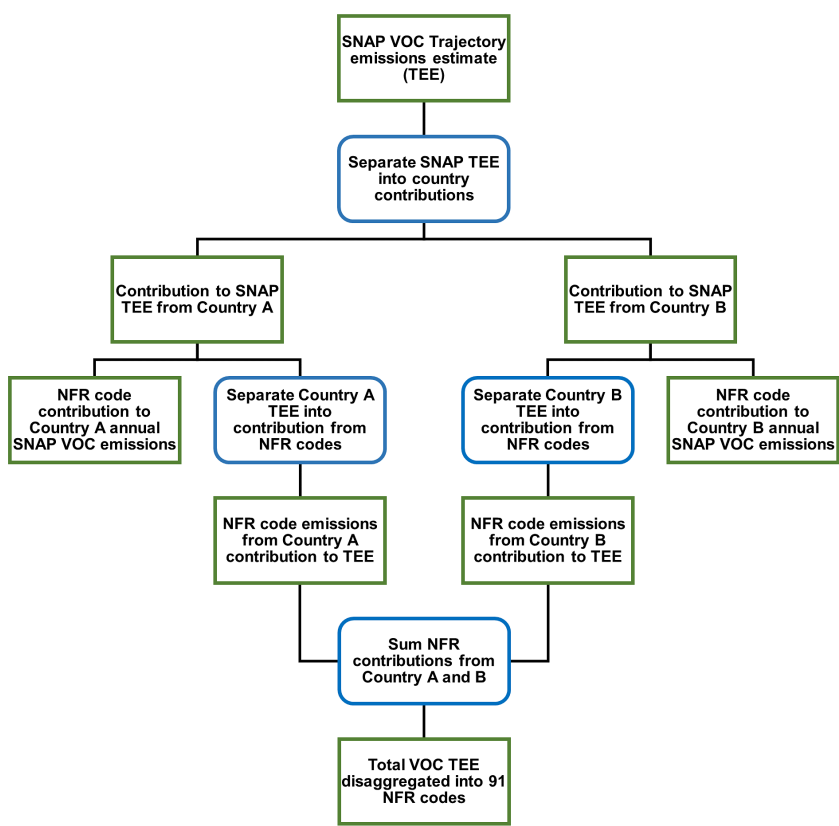

Figure 3. Flowchart representing the process used to derive the contribution from NFR codes to monthly TEE. The green rectangles represent products or data sets, and the blue rounded rectangles represent processes applied to transform a data set. Note that the separation of the TEE into contributions from two countries is illustrative, and in most cases a greater number of countries contributed to the TEE in a given month. Further explanation is provided in Sect. 2.3.

annual SNAP sector emissions. The VOC TEE from each of the 91 NFR codes for each country were summed across all countries to obtain the contribution of each NFR code to the total VOC TEE for each month (Fig. 3).

The emission inventories used in this study have several sources of uncertainty (EEA, 2013; Koohkan et al., 2013). The $0.5^{\circ} \times 0.5^{\circ}$ grid squares mean that numerous distinct sources, each with uncertainties in emission factors and activity rates, are aggregated together to produce the estimate of emissions from a particular SNAP or NFR source sector. The size of the grid square also does not necessarily reflect the size of the area from which emissions influence the atmospheric composition of the trajectory air mass as it passes over. The VOC TEE is therefore used as a relative comparison spatially and temporally, rather than a definitive quantification of the VOC emissions emitted into an air mass. In addition, there are uncertainties in the speciation of total VOC emissions to individual components (Borbon et al., 2013). However, the emission inventories used here are the best estimate of the spatial distribution of anthropogenic VOC emissions across Europe. While studies have shown discrepancies between the EMEP emission inventory and other estimates of European emissions (Koohkan et al., 2013), EMEP gridded emissions have also been shown previously to capture 
variation in VOC measurement data (Sauvage et al., 2009; Derwent et al., 2014).

\section{Results and discussion}

\subsection{Impact: regional $\mathrm{O}_{3}$ production/destruction assessment}

The difference between hemispheric background $\mathrm{O}_{3}$ concentrations and regional background $\mathrm{O}_{3}$ concentrations relevant for Harwell for 2001 (representative of 1999-2001) and 2011 (representative of 2010-2012), and for Auchencorth in 2012, is shown in Fig. 4. Although there was interannual variability within each time period, the data for these years illustrate the main differences between three different phases of the regional $\mathrm{O}_{3}$ increment chemical climate both temporally at Harwell (1999-2001 vs. 2010-2012) and spatially (Harwell vs. Auchencorth). At Harwell, in 2001, a positive regional $\mathrm{O}_{3}$ increment occurred in each month between May and September (Fig. 4a). The annual maximum regional $\mathrm{O}_{3}$ increment (i.e. the difference between hemispheric background and regional background $\mathrm{O}_{3}$ concentrations) occurred in the afternoon in July $2001\left(42 \mu \mathrm{g} \mathrm{m}^{-3}\right)$, while monthly regional $\mathrm{O}_{3}$ increments peaked in excess of $20 \mu \mathrm{g} \mathrm{m}^{-3}$ in June and August and in excess of $10 \mu \mathrm{g} \mathrm{m}^{-3}$ in May and September. A similar pattern occurred in 2000, but with a lower annual maximum $\left(26 \mu \mathrm{g} \mathrm{m}^{-3}\right.$ in July). In 1999, positive regional $\mathrm{O}_{3}$ increments were greater, extending from April to September with the annual maximum in July $\left(53 \mu \mathrm{g} \mathrm{m}^{-3}\right)$, and increments in excess of $30 \mu \mathrm{g} \mathrm{m}^{-3}$ in June and August. In 2011, at Harwell, positive regional $\mathrm{O}_{3}$ increments occurred between April and September (Fig. 4b) but their magnitudes were reduced compared with the 19992001 phase. Only 2 months, April and July, had maximum regional $\mathrm{O}_{3}$ increments $>10 \mu \mathrm{g} \mathrm{m}^{-3}\left(11\right.$ and $32 \mu \mathrm{g} \mathrm{m}^{-3}$, respectively). In 2012, the monthly regional $\mathrm{O}_{3}$ increment exceeded $10 \mu \mathrm{g} \mathrm{m}^{-3}$ in May $\left(12 \mu \mathrm{g} \mathrm{m}^{-3}\right)$, July $\left(28 \mu \mathrm{g} \mathrm{m}^{-3}\right)$ and August $\left(11 \mu \mathrm{g} \mathrm{m}^{-3}\right)$ and occurred more modestly in April, June and September. In 2010, the regional $\mathrm{O}_{3}$ increment in June was $24 \mu \mathrm{g} \mathrm{m}^{-3}$, which then decreased in July $\left(19 \mu \mathrm{g} \mathrm{m}^{-3}\right)$. Reductions in regional $\mathrm{O}_{3}$ have been reported in the UK previously, using high-percentile $\mathrm{O}_{3}$ concentrations as an indicator of regionally derived episodes, rather than calculation of the average monthly-diurnal regional $\mathrm{O}_{3}$ increment. For example, Munir et al. (2013) attributed negative trends in highest $\mathrm{O}_{3}$ concentrations calculated at $22 \mathrm{UK}$ monitoring sites (13 sites with significant trends) to regional reduction in $\mathrm{O}_{3}$ precursor emissions between 1993 and 2011.

The regional $\mathrm{O}_{3}$ increments at Auchencorth were substantially lower than at Harwell. Between 2010 and 2012, the maximum regional $\mathrm{O}_{3}$ increment observed was $14 \mu \mathrm{g} \mathrm{m}^{-3}$ in July 2011. In 2012 (Fig. 4c), the maximum regional $\mathrm{O}_{3}$ increment was $4 \mu \mathrm{g} \mathrm{m}^{-3}$. The spatial differences in the extent of regional contribution to $\mathrm{O}_{3}$ variation at Harwell and Auchen-
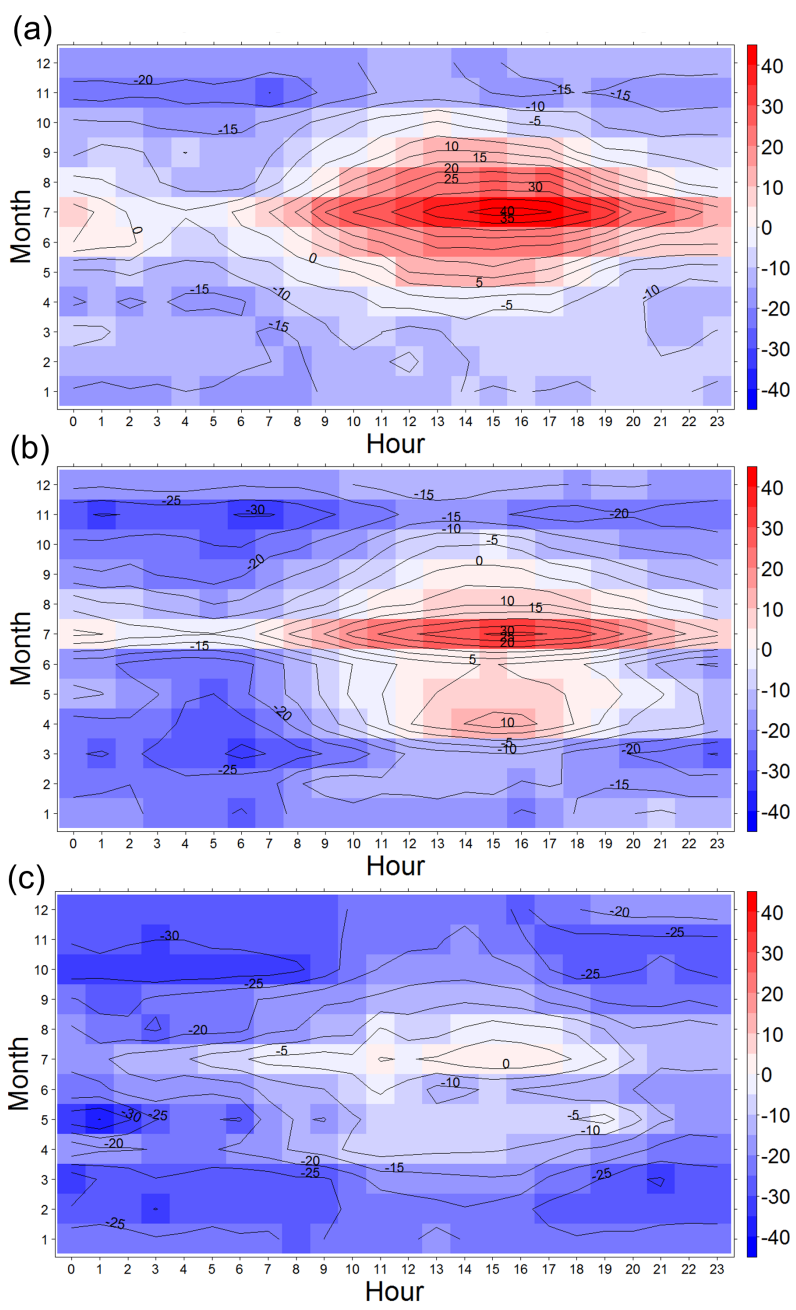

Figure 4. Monthly-hourly average differences between hemispheric background $\mathrm{O}_{3}$ and regional background $\mathrm{O}_{3}$ concentrations $\left(\mu \mathrm{g} \mathrm{m}^{-3}\right.$ ) for (a) 2001 and (b) 2011 in south-east England, the area for which Harwell is representative, and (c) the difference between hemispheric and measured $\mathrm{O}_{3}$ concentrations for 2012 at Auchencorth.

corth are consistent with a previous study of rural $\mathrm{UK} \mathrm{O}_{3}$ spatial variability (Jenkin, 2008).

\subsection{State: VOC concentration and chemical depletion}

The monthly median concentrations of the 27 VOCs measured at Harwell and Auchencorth have a pronounced seasonal cycle with highest total summed VOC concentrations in winter at each site, albeit with concentrations at Auchencorth substantially lower than at Harwell (Fig. 5 shows an example year for each of the three periods). Monthly variation was lower at Auchencorth: the difference between minimum and maximum monthly total median VOC concentrations at Auchencorth in 2012 was $6.2 \mu \mathrm{g} \mathrm{m}^{-3}$, compared with 9.5 and $13.1 \mu \mathrm{g} \mathrm{m}^{-3}$ at Harwell in 2011 and 2001, respectively. Monthly median total VOC concentrations at Har- 

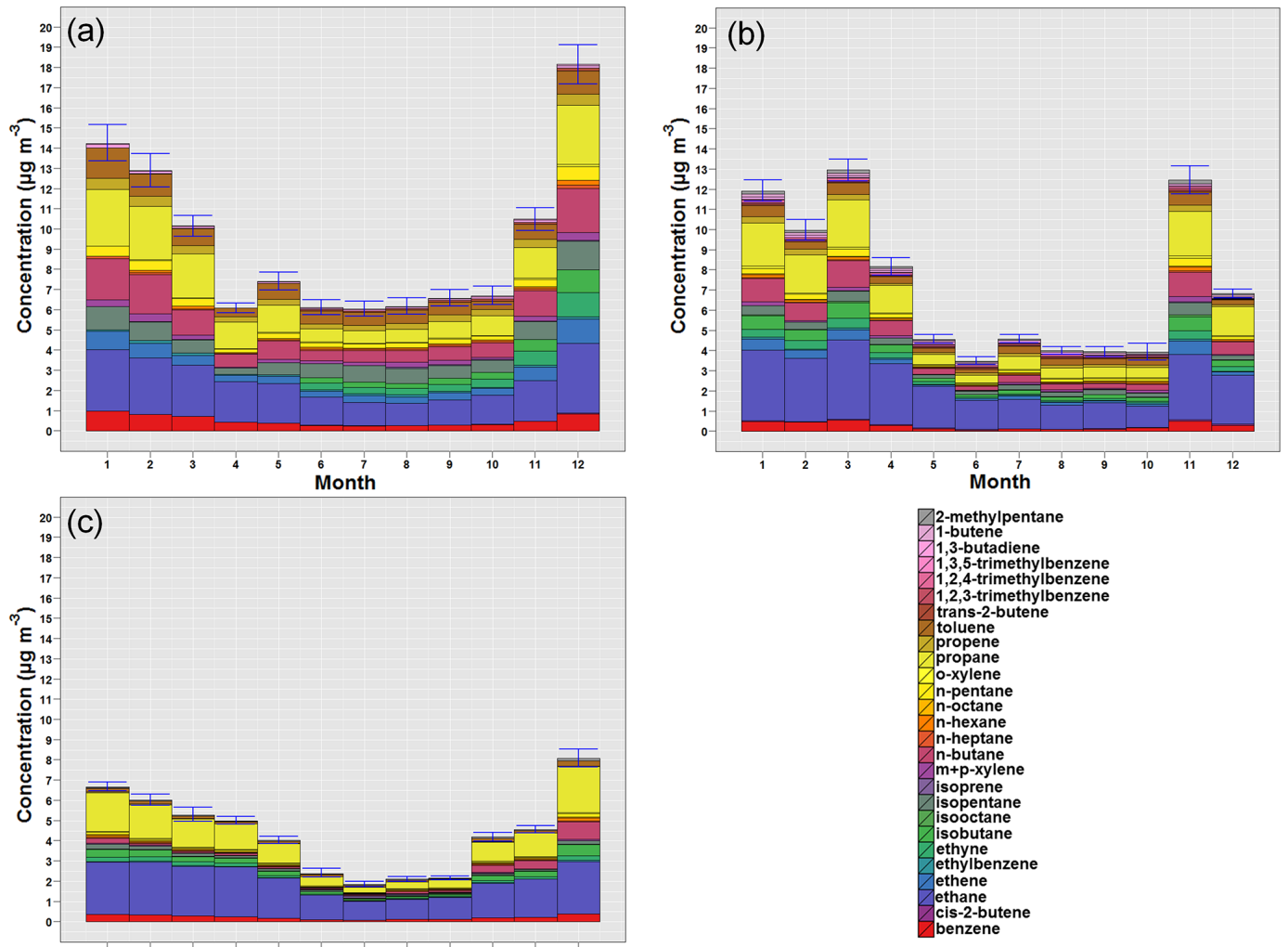

Figure 5. Stacked bar chart of median VOC concentrations at (a) Harwell 2001, (b) Harwell 2011, and (c) Auchencorth (2012). The error bars show the sum of the 95th percentile confidence interval in the median VOC concentrations. This represents the error introduced by representing the data set with the chosen fitted distribution (see text).

well in 1999-2001 and 2010-2012 were similar in winter months (January, February, December) and generally ranged between 6 and $18 \mu \mathrm{g} \mathrm{m}^{-3}$. In summer (June, July, August), between 1999 and 2001, total VOC concentrations were between 5 and $13 \mu \mathrm{g} \mathrm{m}^{-3}$ but between 2010 and 2012 concentrations were lower, between 3 and $6 \mu \mathrm{g} \mathrm{m}^{-3}$, and only June 2010 had higher total VOC concentrations than the summer month in 1999-2001 with the lowest total VOC concentration. In 2001 six VOCs were not measured, and these constituted between 2.1 and $7.4 \%$ of monthly total measured VOC concentrations in 2011. The non-measurement of these VOCs does not alter the conclusions relating to the differences in total VOC concentrations observed between 19992001 and 2010-2012.

The relative composition of total measured VOCs showed differences between 2001 and 2011 at Harwell. Ethane, propane and $n$-butane had the largest measured concentrations. Ethane contributed on average $22 \pm 4 \%$ of total monthly measured VOC concentrations in 2001, compared with $33 \pm 6 \%$ in 2011 (annual average monthlymeasured ethane concentration had a small increase from $2.0 \pm 0.8 \mu \mathrm{g} \mathrm{m}^{-3}$ in 2001 to $2.3 \pm 1 \mu \mathrm{g} \mathrm{m}^{-3}$ in 2011), while the relative contribution from propane did not vary $(15 \%$ in each year, average monthly concentrations in 2001 and 2011 were $1.5 \pm 0.9$ and $1.2 \pm 0.8 \mu \mathrm{g} \mathrm{m}^{-3}$, respectively) and that from $n$-butane decreased from $11 \pm 2$ to $8 \pm 1 \%$ $\left(1.1 \pm 0.6 \mu \mathrm{g} \mathrm{m}^{-3}\right.$ in 2001 and $0.6 \pm 0.4 \mu \mathrm{g} \mathrm{m}^{-3}$ in 2011). Although these differences are not large, they may result from differences in the reduction of VOC emission sources between 1999-2001 and 2010-2012. The aim of this work, however, was not the determination of long-term trends in absolute VOC concentrations, and the reader is referred to Dollard et al. (2007), von Schneidemesser et al. (2010) and Derwent et al. (2014) which have undertaken analyses of trends in VOC concentrations at multiple UK sites, including Harwell and Auchencorth.

The extent of diurnal photochemical loss of VOCs over the year is shown in Fig. 6. At Harwell, periods of increased VOC diurnal photochemical depletion mirror the monthly magnitude of regional $\mathrm{O}_{3}$ increments (Fig. 4 cf. Fig. 6). In 2001, at Harwell, both the regional $\mathrm{O}_{3}$ increment and VOC diurnal photochemical depletion increased from June to July, before declining in August. In 2011 there was a local maximum in the regional $\mathrm{O}_{3}$ increment in April, followed by the annual maximum in July, mirrored by VOC diurnal photochemical depletion. During 2012 the regional $\mathrm{O}_{3}$ increment 

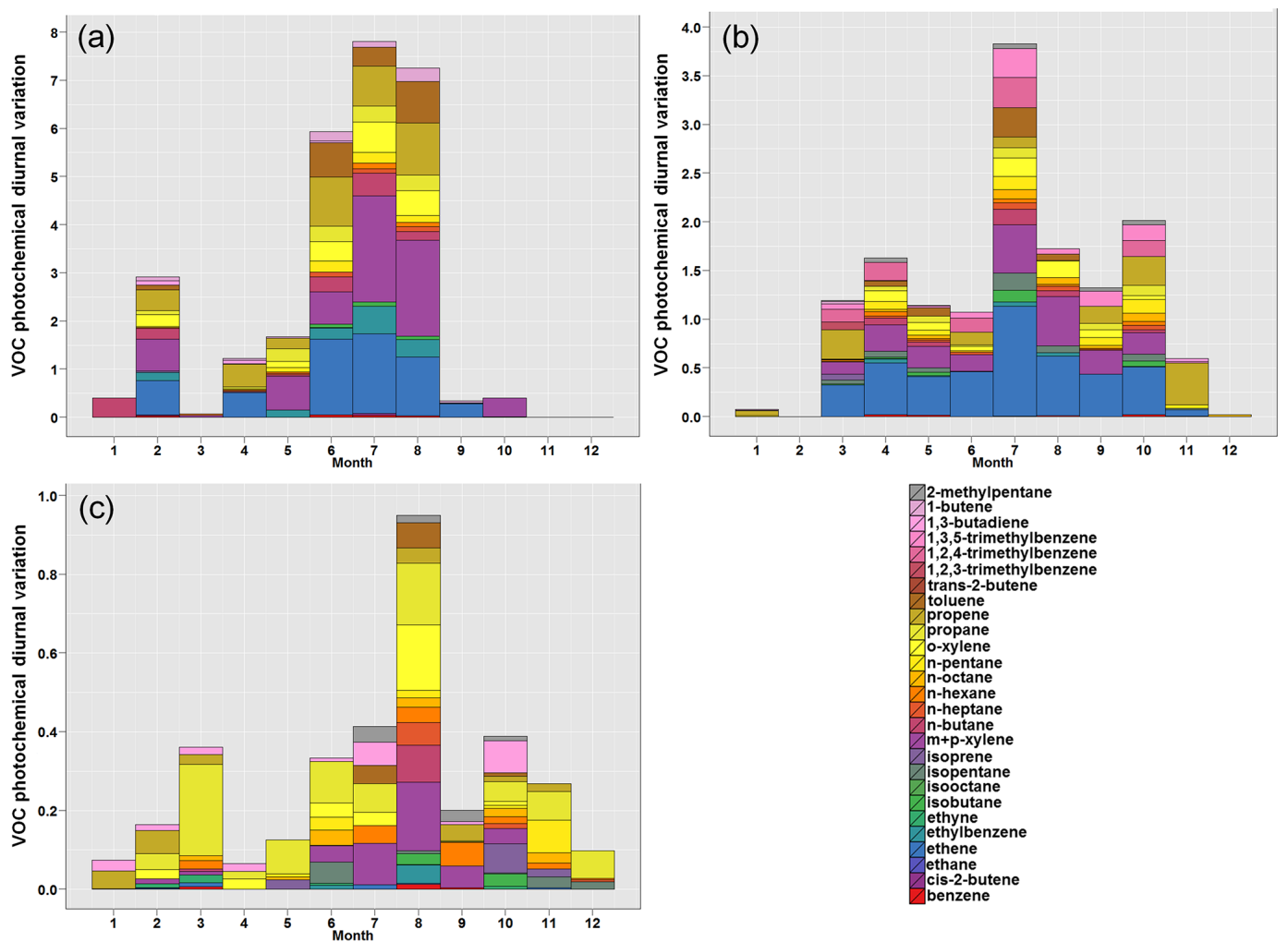

Figure 6. Monthly variation in VOC diurnal photochemical reactivity as defined by the difference between night (average of 01:00-05:00) and afternoon (13:00-17:00) POCP-weighted VOC / ethane ratios for (a) Harwell 2001, (b) Harwell 2011, and (c) Auchencorth 2011. Note the very different vertical scales.

was minimal at Auchencorth, and the magnitude of VOC diurnal photochemical depletion was low, with a small peak in August.

The association between the monthly variation in the regional $\mathrm{O}_{3}$ increment and total VOC diurnal photochemical depletion at Harwell indicates that the variation in VOC chemical loss contributing to the regional $\mathrm{O}_{3}$ increment is represented by the VOC diurnal photochemical depletion. The relative contribution of each measured VOC to total VOC diurnal photochemical depletion during months of enhanced regional $\mathrm{O}_{3}$ increment therefore indicates where emission reductions should be targeted to most effectively reduce VOC chemical loss and hence to reduce the magnitude of the regional $\mathrm{O}_{3}$ increment. The contributions of each measured VOC to total VOC diurnal photochemical depletion during the month of maximum regional $\mathrm{O}_{3}$ increment in 2010, 2011 and 2012 at Harwell are shown in Fig. 7. A positive value indicates lower POCP-weighted VOC / ethane ratio during the afternoon compared to night (i.e. photochemical depletion). A higher POCP-weighted VOC / ethane ratio during the afternoon results in the negative value. Ethene had the largest contribution during these months (34, 29 and $45 \%$ of total measured VOC diurnal reactivity in 2010, 2011 and 2012, respectively). The sum of $m+p$-xylene also made a major positive contribution during $2010(15 \%)$ and 2011 $(13 \%)$. The majority of the remaining measured VOCs made smaller, positive contributions. In July $2011,71 \%$ of the remaining VOCs (i.e. all VOCs excluding ethene and $m+p$ xylene) contributed on average $3.4 \pm 2.5 \%$ to total positive VOC diurnal variation. In July 2012, the maximum regional $\mathrm{O}_{3}$ increment was $12 \%$ lower than July 2011, and only $58 \%$ of the remaining VOCs made positive contributions. In June 2010, the maximum regional $\mathrm{O}_{3}$ increment was $25 \%$ lower, and $54 \%$ of the remaining VOCs contributed. VOCs with larger VOC/ethane ratios in the afternoon included isoprene, which is predominantly of biogenic origin (von Schneidemesser et al., 2011). Laurent and Hauschild (2014) modelled the impact on $\mathrm{O}_{3}$ formation of speciated VOC emissions from 31 countries and also reported $m$-xylene and ethene to have the largest impact of 270 VOCs on regional $\mathrm{O}_{3}$ formation.

Figure 8 is the analogous plot to Fig. 7 for 1999-2001 at Harwell. In 1999-2001, $m+p$-xylene had the largest diurnal photochemical depletion, followed by ethene. However, there were much larger negative VOC / ethane diurnal variations for some anthropogenic VOCs compared to 2010 2012 (Fig. 5), i.e. afternoon POCP-weighted VOC / ethane ratios were substantially higher than at night. This indicates 
that processes other than photochemical depletion, e.g. local emission patterns, contributed to diurnal variation in POCPweighted VOC / ethane ratios for these VOCs in 1999-2001. Isopentane had the largest negative difference but had a consistent positive contribution in 2010-2012. Toluene also had a negative value in 1999 and 2000. Therefore, from 19992001 to 2010-2012 there was a change in the balance between emissions of isopentane and toluene and their photochemical removal to the point where photochemical depletion dominated during the day, and VOC / ethane ratios were lower in the afternoon than at night. Derwent et al. (2014) calculated exponential decreases in the concentrations of these VOCs at urban locations in the south-east of England, where Harwell is located, attributed to the effective control of evaporative and exhaust emissions from petrol-engine vehicles. Toluene has an atmospheric lifetime of $\sim 1.9$ days with respect to reaction with $\mathrm{OH}$ (Atkinson, 2000), so local daytime toluene emissions would not deplete substantially during transport to the monitoring site. The observed decreasing trends at sites close to emission sources in the south-east of England suggest a decrease in the influence of local isopentane and toluene emissions in determining the diurnal profile of these VOCs at Harwell and hence afternoon depletion of regionally emitted toluene and isopentane was observed in 2010-2012.

\subsection{Drivers of chemical climate state: meteorology and emissions}

\subsubsection{Meteorology}

The monthly-averaged meteorological data for the UK regions relevant for Harwell in 2001 and 2011 and Auchencorth in 2012 are shown in Fig. 9. Variation in temperature and sunshine is often associated with spatiotemporal differences in VOC diurnal photochemical depletion and regional $\mathrm{O}_{3}$ increment. For example, temperatures were generally lower in East Scotland than South East and Central South England but the number of hours of sunshine were comparable, although solar intensity is less in Scotland, hence a reduced VOC photochemical depletion and regional $\mathrm{O}_{3}$ increment at Auchencorth. At Harwell, in 2001, annual maximum VOC diurnal photochemical depletion occurred in July, coinciding with annual maximum monthly temperature, while in July 2011 a combination of relatively high temperature and hours of sunshine (although neither were annual maxima) coincided with annual maximum VOC diurnal photochemical depletion. These summers were typical of the 1999-2012 period; monthly mean temperatures were between -7 and +4\% compared to the 1999-2012 average, and hours of sunshine were between -14 to $+11 \%$ compared to the average.

However, not all variation in VOC diurnal photochemical depletion and regional $\mathrm{O}_{3}$ increment were associated with changes in meteorology. For example, at Harwell, in April 2011 there was a larger regional $\mathrm{O}_{3}$ increment compared with
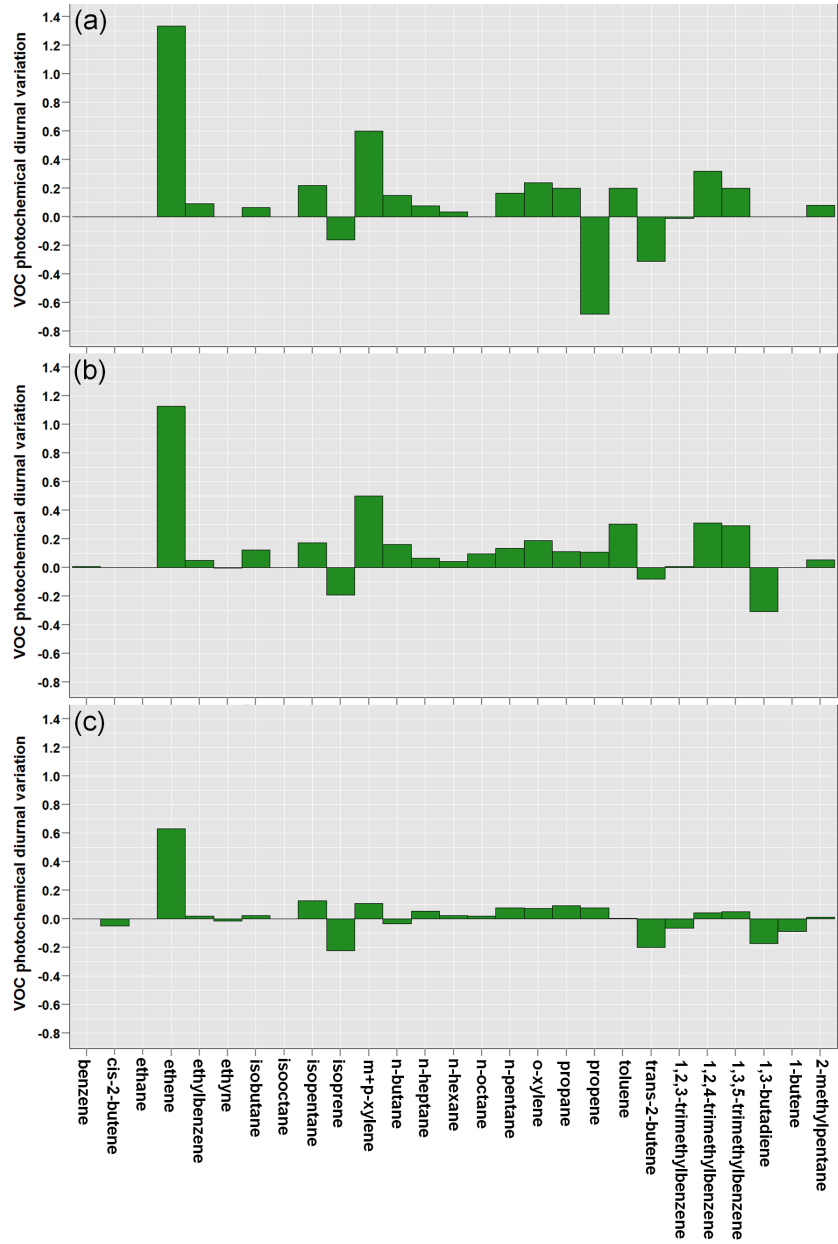

Figure 7. Individual VOC diurnal photochemical reactivity as defined by the difference between night (average of 01:00-05:00) and afternoon (13:00-17:00) POCP-weighted VOC / ethane ratios for (a) June 2010, (b) July 2011 and (c) July 2012 at Harwell. A lower ratio in the afternoon results in a positive value (i.e. photochemical depletion), while a higher afternoon ratio results in a negative value. These months correspond to the periods of annual maximum regional $\mathrm{O}_{3}$ increment at Harwell (see Fig. 2).

April 2001. This coincided with a $4{ }^{\circ} \mathrm{C}$ higher mean temperature and 95 more hours of sunshine in South East and Central South England. In May 2011 the temperature and sunshine were similar to April 2011, but VOC diurnal photochemical depletion and the regional $\mathrm{O}_{3}$ increment decreased. Hence, other factors, such as the strength of VOC emission sources over which an air mass passes, also influence VOC diurnal photochemical depletion and are discussed in Sect. 3.3.2.

\subsubsection{Emissions}

Variation in the monthly-averaged European anthropogenic VOC TEE is shown in Fig. 10. The VOC TEE is the sum of hourly emissions from the grid squares the trajectories passed over in the $96 \mathrm{~h}$ prior to arrival at the supersites 

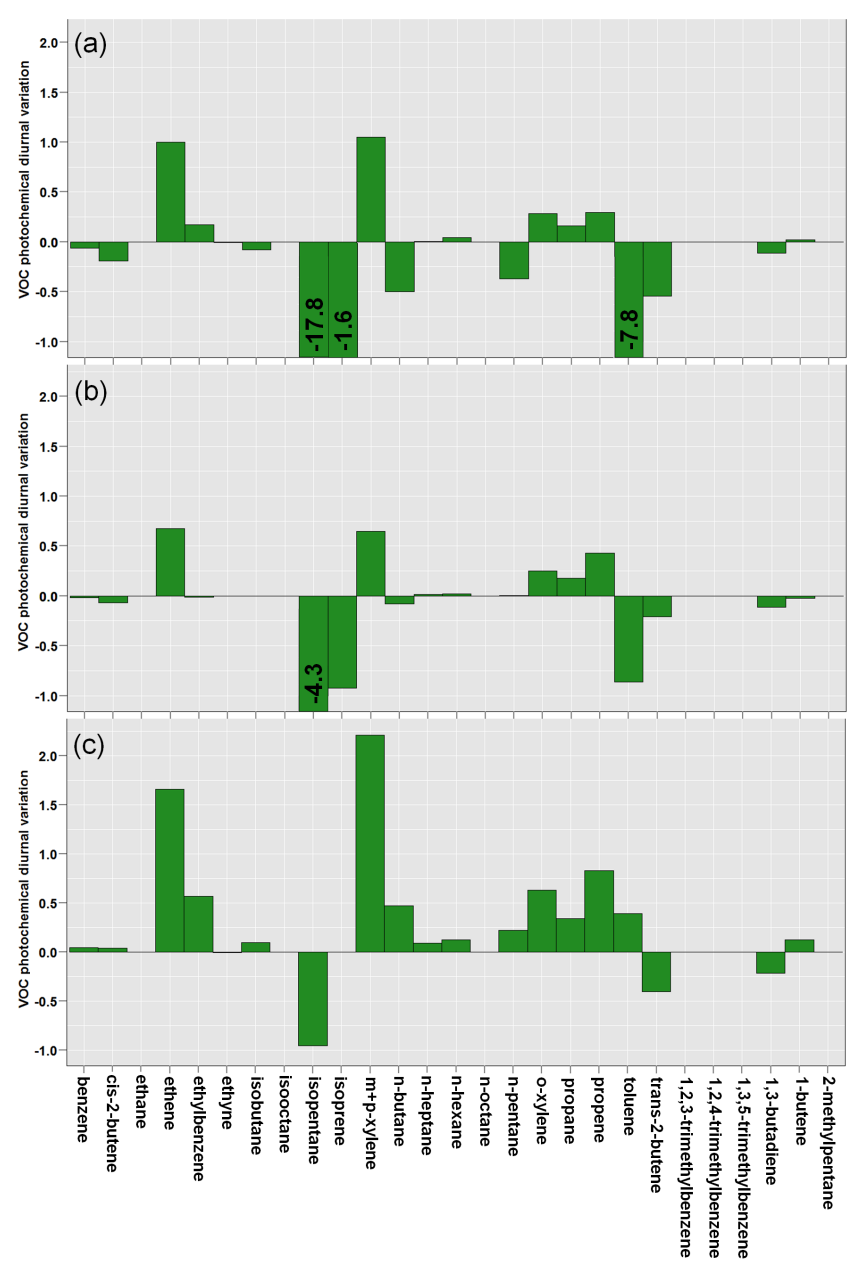

Figure 8. Individual VOC diurnal photochemical reactivity as defined by the difference between night (average of 01:00-05:00) and afternoon (13:00-17:00) POCP-weighted VOC / ethane ratios in (a) July 1999, (b) July 2000 and (c) July 2001 at Harwell. A lower ratio in the afternoon results in a positive value (i.e. photochemical depletion), while a higher afternoon ratio results in a negative value. These months correspond to the periods of annual maximum regional $\mathrm{O}_{3}$ increment. To emphasise the positive contributions to VOC photochemical cycling, the negative values have been truncated.

(unit: $\mathrm{Mg} 96 \mathrm{~h}^{-1}$ ), rather than a definitive quantification of the emissions directly impacting upon the measured atmospheric composition at the supersites. Compared with Harwell in 2001, the annual average VOC TEE, by mass, was $64 \%$ smaller in 2011 at Harwell and 76\% smaller in 2012 at Auchencorth. For the purposes of clarity the following assessment focuses on Harwell, where significant regional $\mathrm{O}_{3}$ increment has been demonstrated (Sect. 3.1). The biggest change in contribution from the 11 SNAP sectors to average VOC TEE between 2001 and 2011 at Harwell was for SNAP 7 (road transport), which averaged $31 \%$ of the total 10 VOC TEE in 2001, compared with $9 \%$ in 2011 (Fig. 10). The
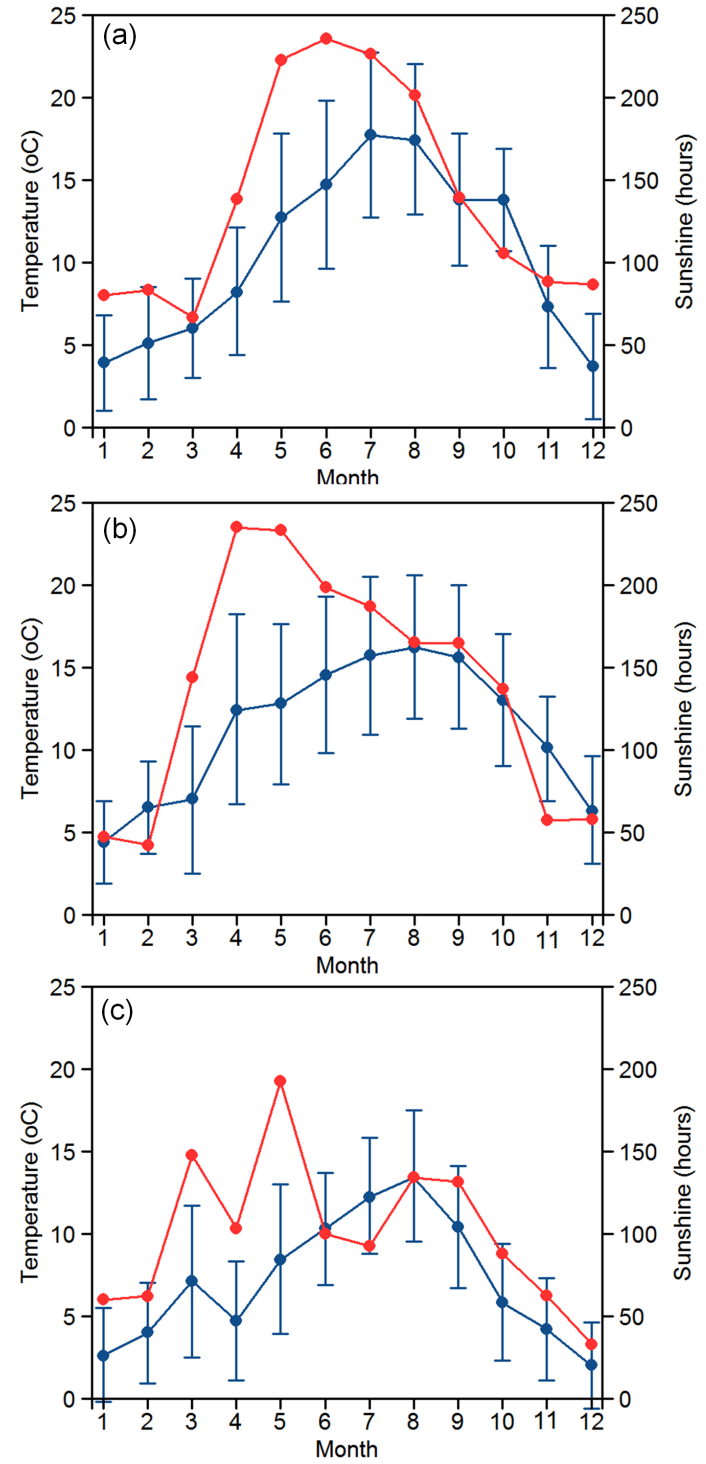

Figure 9. Average monthly mean temperatures (blue, maximum and minimum temperatures shown as whiskers) and hours of sunshine (red) from the UK Meteorological Office (http://www.metoffice. gov.uk/climate/uk/datasets/\#) for (a) South East and Central South England 2001, (b) South East and Central South England 2011 and (c) East Scotland 2012.

biggest change was for SNAP 7 (road transport), which averaged $31 \%$ of the total VOC TEE in 2001, compared to $9 \%$ in 2011. Emissions from SNAP 6 (solvents) were the largest contribution to the VOC TEE during both periods, contributing $50 \%$ of total emissions on average in 2011, compared to $34 \%$ in 2001. Emissions from SNAP 4 (production processes) were the second largest contributor on average in 2011 (11\% of the total VOC TEE), followed by SNAP 7 (road transport), and SNAP 5 (extraction and distribution of fossil fuels), both contributing $9 \%$. 

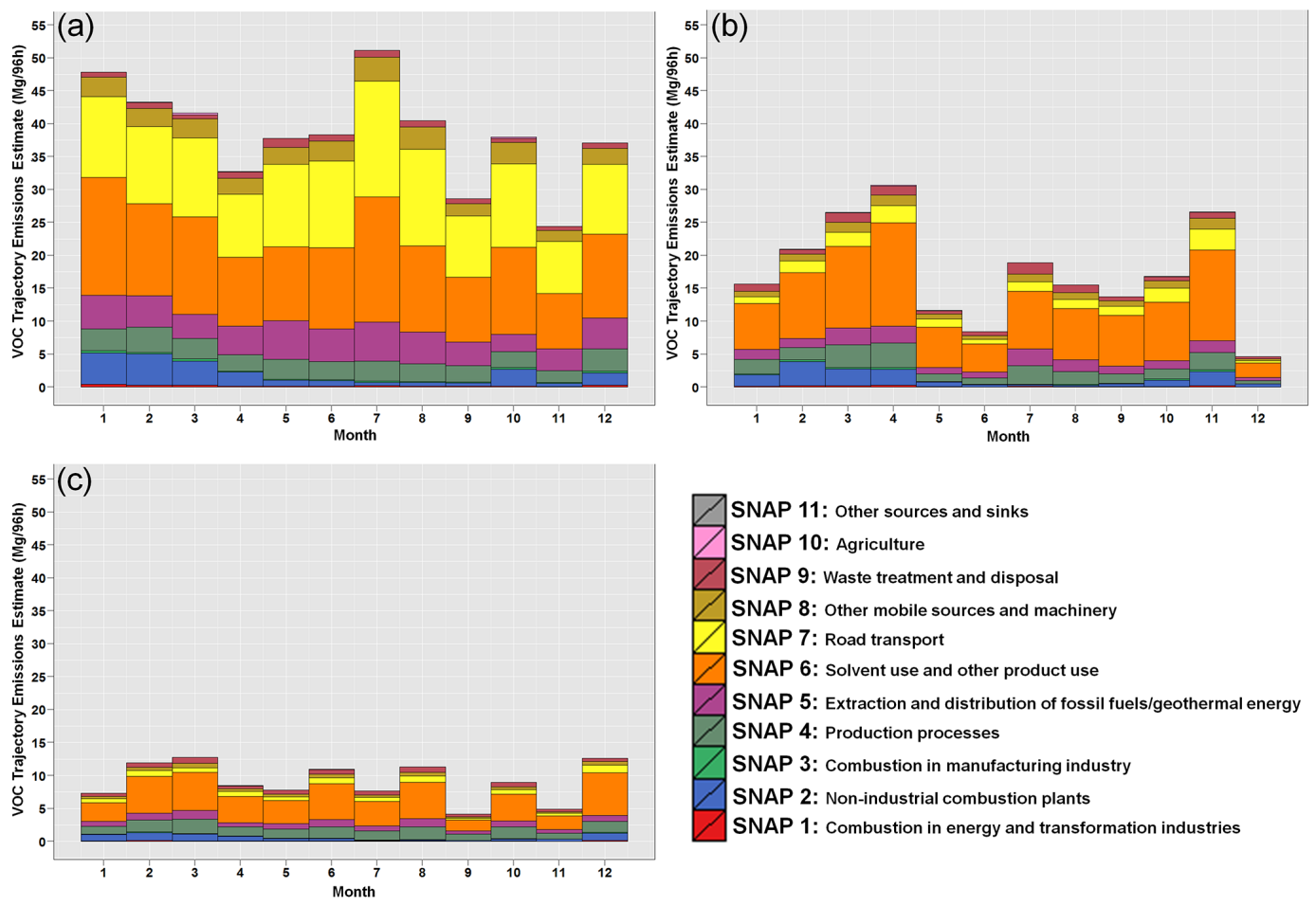

SNAP 11: Other sources and sinks

SNAP 10: Agriculture

SNAP 9: Waste treatment and disposal

SNAP 8: Other mobile sources and machinery

SNAP 7: Road transport

SNAP 6: Solvent use and other product use

SNAP 5: Extraction and distribution of fossil fuels/geothermal energy

SNAP 4: Production processes

SNAP 3: Combustion in manufacturing industry

SNAP 2: Non-industrial combustion plants

SNAP 1: Combustion in energy and transformation industries

Figure 10. Monthly-average VOC $96 \mathrm{~h}$ back-trajectory emission estimates prior to arrival at the receptor site, disaggregated into 11 SNAP source sectors for (a) Harwell 2001, (b) 2011 Harwell, and (c) Auchencorth 2012.

Monthly variation in VOC TEE mirrors that of VOC diurnal photochemical depletion and hence the magnitude of the regional $\mathrm{O}_{3}$ increment. The period of April-July 2011 provides a useful case study to demonstrate the nature of the emissions driver. This period shows how variation in both the magnitude of the VOC TEE, as well as the proportion of emissions emitted closer to the receptor site (temporally) can influence the extent of VOC diurnal photochemical depletion and the magnitude of the regional $\mathrm{O}_{3}$ increment. April and May 2011 have similar meteorological conditions (Fig. 9), but VOC diurnal photochemical depletion was lower in May due to a $62 \%$ decrease in the VOC TEE compared to April. The VOC TEE decreased in June, then increased in July. This latter increase, coupled with increased temperatures and solar intensity in summer, provided conditions conducive to producing the observed annual maximum in VOC diurnal photochemical depletion for 2011.

The proportion of the total VOC TEE derived from the final $4 \mathrm{~h}$ prior to a trajectory's arrival, plus the hour of arrival, was labelled as the "final $4 \mathrm{~h}$ " VOC TEE to investigate the effect of variation in the proportion of emissions emitted closer to the monitoring site. In 2011 the final $4 \mathrm{~h}$ was on average $28 \%$ of the total VOC TEE (Fig. 11a). In May and June 2011 it was above average (36 and $44 \%$, respectively) and in April and July it was lower (17 and $20 \%$, respectively). While the $4 \mathrm{~h}$ cut-off for this calculation was somewhat arbitrary, it was based on consideration of the average atmospheric lifetimes of the individual VOCs (Atkinson, 2000) which indicate that most VOCs emitted in the final $4 \mathrm{~h}$ have insufficient time to form $\mathrm{O}_{3}$. Between June and July 2011 there was a $32 \%$ increase in median VOC concentrations due to an increased VOC TEE (Fig. 11b). However, there was a $275 \%$ increase in VOC diurnal photochemical depletion as a larger proportion of emissions were emitted earlier along the air-mass trajectory (Fig. 11c). Hence, in May and June, lower total VOC TEE compared to April and July, respectively, coupled with a larger proportion of VOCs emitted in the final $4 \mathrm{~h}$, resulted in the reduced regional $\mathrm{O}_{3}$ increment impact (Fig. 11d).

The speciated VOC monthly trajectory emission estimates, based on a UK-specific speciation of the total VOC TEE for nine SNAP sectors, are shown in Fig. 12 for July 2001 and 2011. Individual VOC trajectory emission estimates were expressed as the percentage of the total POCP-weighted emissions and the comparison between 2001 and 2011 illustrates the contrast and similarities in contribution from individual VOCs to the VOC TEE during the months of maximum regional $\mathrm{O}_{3}$ increment. The biggest decreases between 2001 and 2011 were for isopentane $(4.1 \%$ total POCP emissions in $2001,1.7 \%$ in 2011$)$, and toluene $(6.5 \%$ in $2001,4.5 \%$ in 2011). These decreases mirror the absence of much greater POCP-weighted VOC / ethane ratios in the afternoon compared to night for toluene and isopentane in 2010-2012, which were observed in 1999-2001 and attributed to variation in local emissions (discussed in Sect. 3.2 and visu- 


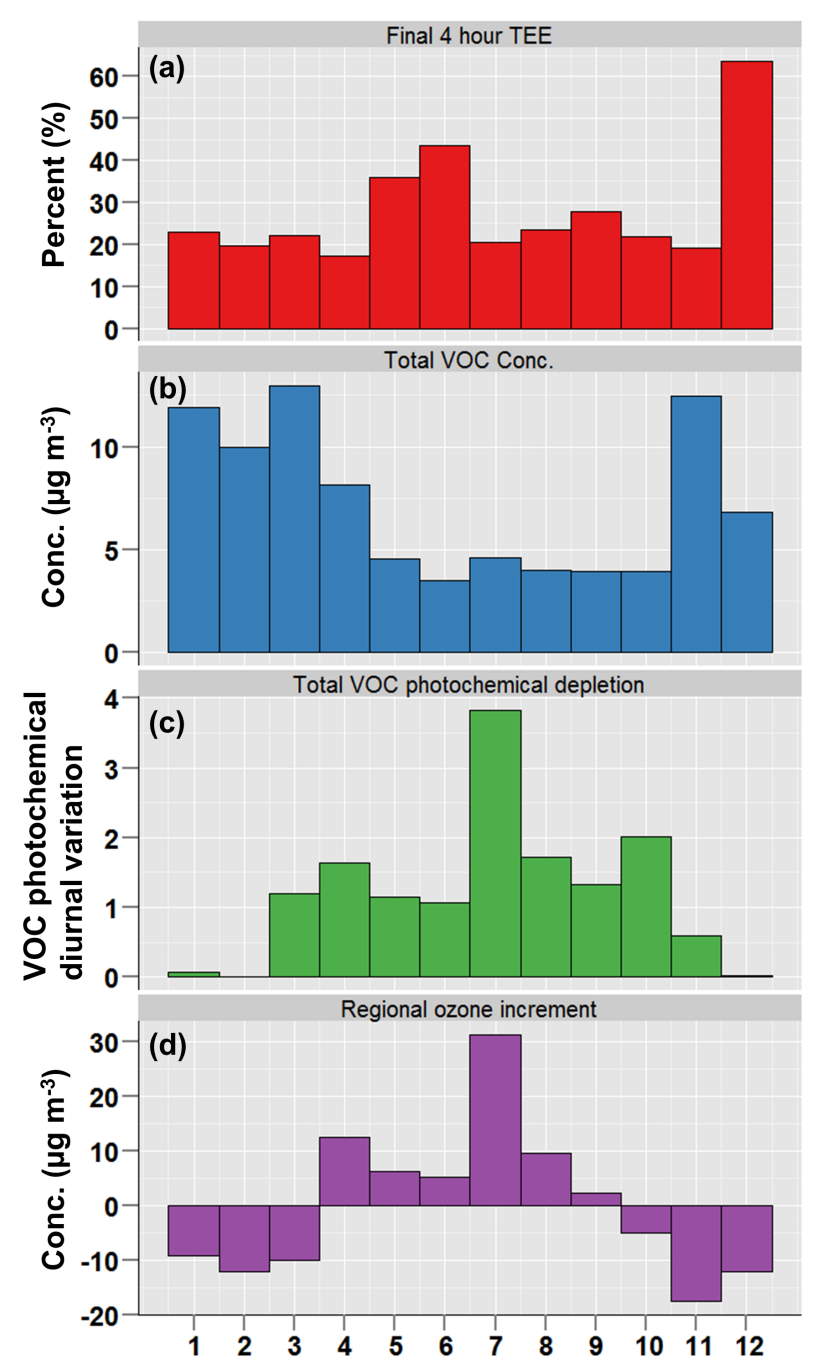

Figure 11. Summary of variables relevant to the assessment of the effect of variation in the proportion of emissions accumulated close (temporally) to the monitoring site: (a) the final $4 \mathrm{~h}$ TEE metric, i.e. the proportion of the TEE emitted into the air mass during the $4 \mathrm{~h}$ prior to arrival at the site (defined in Sect. 3.3.2), (b) monthlyaverage sum of measured VOCs, (c) monthly-average sum of VOC diurnal photochemical depletion, (d) monthly maximum difference between hemispheric background concentrations and regional background concentrations (a positive value indicates additional regional $\mathrm{O}_{3}$ production).

alised as "negative" VOC diurnal photochemical depletion in Figs. 7 and 8)

Monthly variation in the contribution of measured VOCs to the VOC TEE was not consistent with variation in the contribution of individual VOCs to total measured VOC diurnal photochemical depletion. This is in contrast to the observed changes between 2001 and 2011 in VOC contribution to TEE and VOC diurnal photochemical depletion and is effectively illustrated using the April-July 2011 time period as an example. For example, in 2011, the VOC diur-
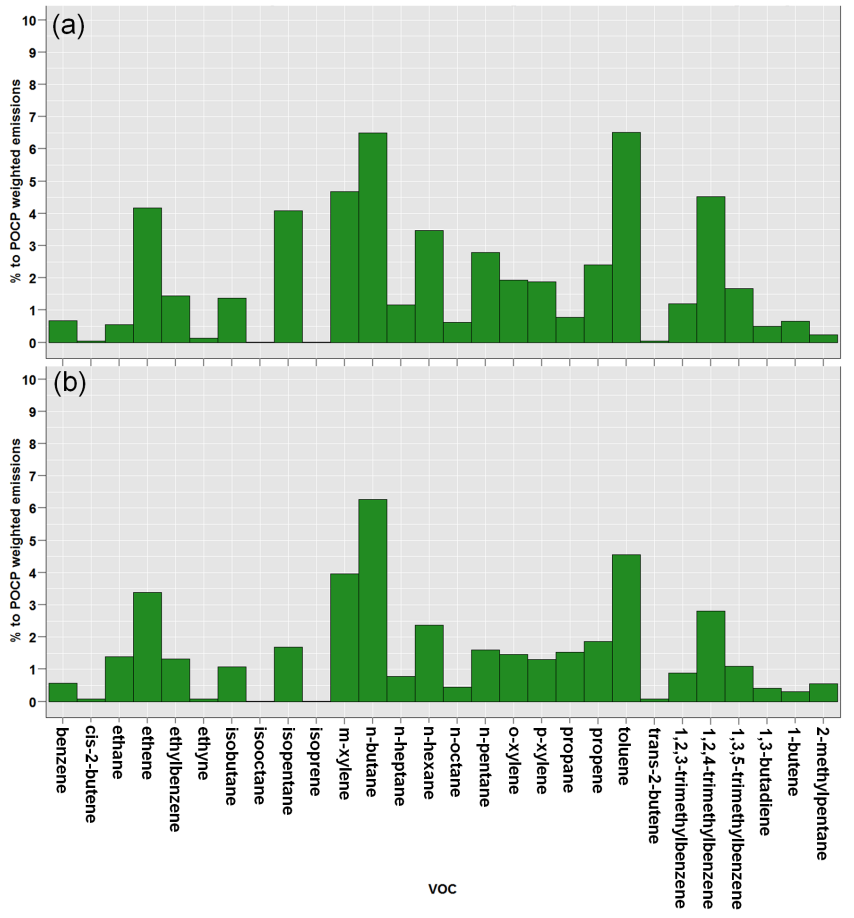

Figure 12. Speciation of average VOC back-trajectory emission estimates in (a) July 2001, and (b) July 2011 at Harwell. The speciation was based on source profiles catalogued in Passant (2002) and the relative contribution of individual activities to annual total VOC emissions.

nal photochemical depletion peak in July (Fig. 6) was much greater than in April due to more intense sunshine and higher temperatures. This increase was not equally reflected across the measured VOCs, indicating differences in the speciation of the VOC TEEs prior to arrival at the site. For example, toluene was $4.2 \%$ of total VOC diurnal photochemical depletion in April, increasing to $9.6 \%$, in July and the 1,3,5trimethylbenzene contribution increased from $0.1 \%$ in April to $8 \%$ in July. The monthly-averaged speciated VOC TEEs do not reflect these changes and show little monthly variation within a given year. The speciated VOC monthly TEE calculation assumes that the SNAP sector component activities (i.e. the activities for which speciated profiles are defined; Passant, 2002) contribute similarly to the emissions exposure of the parent SNAP sector in each month of the year. For example, it is assumed that an $x \%$ increase in SNAP emissions results from an $x \%$ increase in emissions from all component activities. It is unlikely that the SNAP sector emissions in every region over which an air mass travels are similarly apportioned between component emission activities. The inability of this method to account for these spatial differences will result in the underestimation of the TEE of some VOCs, and the overestimation of others. Currently, data are only available on changes in the contribution of more narrowly defined NFR codes to SNAP sector emissions at a country level and 


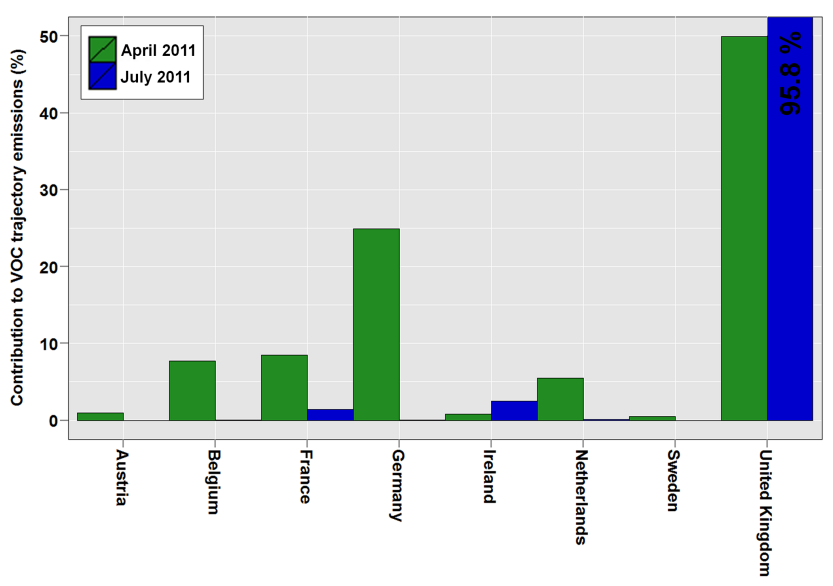

Figure 13. Contributions to the average VOC $96 \mathrm{~h}$ back-trajectory emission estimates in April 2011 (green bars) and July 2011 (blue bars) from countries which contributed at least $0.5 \%$ during one of the months. The contribution of the UK in July 2011 was $95.8 \%$ and has been truncated in the plot.

for annual VOC emissions. In 2011 the average contribution to monthly VOC TEE at Harwell from the UK was $62 \%$, with France the second largest contributor at $14 \%$. Comparing April and July 2011, the contributions from the UK to the VOC TEE were 50 and $95 \%$, respectively, with the other $50 \%$ in April resulting from contributions from Germany, France, Belgium and the Netherlands (Fig. 13). These countries all have different relative contributions to total SNAP sector emissions from component NFR source sectors (EEA, 2014).

Highly aggregated SNAP source sectors, and a constant contribution of component activities to SNAP emissions were identified as a potential contributing factor to inconsistencies between VOC contributions to TEE and VOC diurnal photochemical depletion. Disaggregation of the VOC TEEs into 91 NFR codes, based on country-specific contributions of these NFR codes to annual VOC emissions in the 11 parent SNAP sectors, accounted for country-specific changes in NFR sector contributions to monthly VOC TEE at Harwell. The aim was to show that within each SNAP sector an increase in VOC SNAP emissions can result from an increase in a specific source activity (e.g. specific NFR code), rather than a general overall increase. Variability in the contribution of constituent activities to SNAP emissions could result in variation in the contribution of individual VOCs to those emissions. This would therefore demonstrate that the reporting of gridded VOC emissions in more disaggregated source sectors was required, so that more flexible VOC speciation profiles could be derived than those calculated for the nine SNAP sectors in this study and those calculated previously, e.g. Derwent et al. (2007a). For example, in 1999-2001, the large contribution from SNAP 7 (road transport; Fig. 10) is more precisely attributed to NFR sectors $1 \mathrm{~A} 3 \mathrm{bi}$ (passenger cars) and $1 \mathrm{~A} 3 \mathrm{bv}$ (gasoline evaporation) which contributed 19 and $11 \%$ to the total VOC TEE in July 2001 (month of maximum regional $\mathrm{O}_{3}$ increment), respectively, and $87 \%$ of the SNAP 7 emissions estimate. The next largest contribution was from 3D2 (domestic solvent use, $10 \%$ ), a component of SNAP 6 (solvents). Between 2010 and 2012, SNAP 6 was the major contributor to the VOC TEE. During July 2011, SNAP 6 component NFR sectors 3D2 (domestic solvent use) and 3D3 (other product use) contributed 18 and $12 \%$ of the total VOC TEE ( $65 \%$ of the SNAP 6 emissions estimate). The SNAP 4 (production processes) component 2D2 (food and drink) was the third largest contributor (10\% in July 2011). The two road transport categories contributed $4 \%$ (1A3bi) and $1 \%$ (1A3bv) to the total VOC TEE in July 2011.

The difference between the contribution of 91 NFR codes to the average VOC TEE between April and July 2011 is shown in Fig. 14 to demonstrate the variability in contribution of component activities to parent SNAP sector emissions. Between these months, the cumulative change in the contribution of the nine SNAP sectors to the total VOC TEE was $13.4 \%$, compared to a change of $15.9 \%$ for the 91 NFR codes. However, the changes in NFR code contributions were not equally spread between the constituent activities of a SNAP sector; they were concentrated in relatively few NFR sectors. For example, between April and July $85 \%$ of the NFR change resulted from a decrease in 10 out of the 91 NFR sectors. The sectors "residential: stationary plant combustion" and "industrial coating application" show the greatest decrease, while sectors "food and drink" and "venting and flaring" show the largest increase (identified by stars in Fig. 14). The disaggregation of SNAP sector VOC TEEs also illustrates changes of opposite sign in the contribution of component NFR sectors under the net changes in SNAP sector. For example, SNAP sector 4 (production processes) increased in contribution between April and July by $2.7 \%$ (12.0-14.7\%). Following disaggregation, this change was seen to result from a $3.4 \%$ increase in NFR sector 2D2 (food and drink) and a $0.76 \%$ decrease in 2B5 (other chemical industry). NFR-sector-level speciated profiles can therefore give much more specific information on the emission source drivers of VOC diurnal photochemical depletion, though it is noted that the accuracy of many emission source speciation profiles is subject to discussion (Borbon et al., 2013). However, the changes in contribution of NFR sectors to the VOC TEE calculated here only account for country-level variation, not for variation in the contribution of NFR sectors to SNAP emissions on finer spatial scales, such as differences in NFR sector contribution to SNAP emissions in different $0.5^{\circ} \times 0.5^{\circ}$ grid squares for which the SNAP-sector-gridded emissions are reported. Hence, the future reporting of gridded emissions to NFR code level would more accurately represent the true nature of VOC emissions across Europe. 


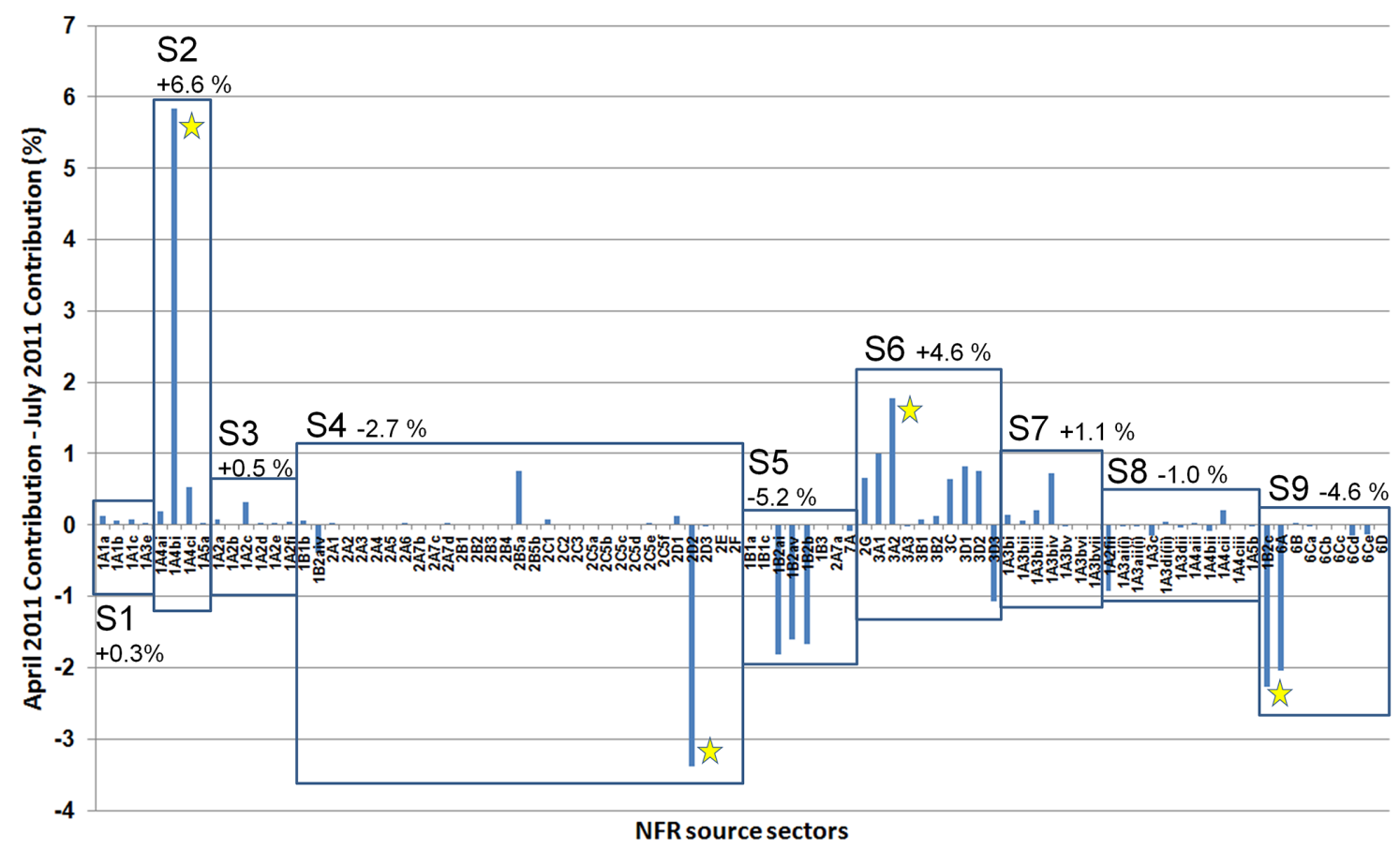

Figure 14. Difference between NFR source sector contributions to average VOC back-trajectory emission estimates (VOC TEE) in April and July 2011 at Harwell. Also shown are the change in contribution of the SNAP source sectors. These were calculated from the VOC TEE prior to disaggregation and do not represent the sum of the contribution changes of the constituent NFR source sectors. The source sectors identified by stars have the largest changes between April and July (Sect. 3.3.2).

\subsection{Uncertainties and implications for future mitigation and monitoring}

Two VOCs, ethene and $m+p$-xylene, consistently had larger contributions to total VOC diurnal photochemical depletion compared to the remaining VOC suite. Therefore, a targeted reduction of these two VOCs (compared to other measured VOCs) would be most effective in reducing the regional $\mathrm{O}_{3}$ increment. Further reduction of total measured VOC diurnal photochemical depletion would require a reduction across a larger number of the remaining measured VOCs. This could be achieved by lowering emissions from large VOC-emitting sources rather than focusing on individual VOC species. As previously identified (Sect. 3.3), between 2010 and 2012, the largest VOC-emitting sources (NFR codes) were 3D2 (domestic solvent use including fungicides), 3D3 (other product use) and 2D2 (food and drink).

The 27 measured VOCs studied here are a subset of the total VOC species emitted by a multitude of anthropogenic activities and biogenic processes. In 2011, 37.5\% of the reported annual UK anthropogenic VOC emissions were emitted as one of the 27 measured VOCs when speciated using the Passant (2002) speciation profiles. The UK biogenic VOC emissions estimate reported to EMEP for 2011 was $91.2 \mathrm{Gg}$ (cf. anthropogenic emissions of $752 \mathrm{Gg}$ ) but this value is uncertain and studies have estimated considerably higher UK annual biogenic VOC emissions, in excess of
200 Gg (Karl et al., 2009; Oderbolz et al., 2013). Biogenic VOC contributions to regional $\mathrm{O}_{3}$ increments were not studied using this methodology. The estimate of $752 \mathrm{Gg}$ of UK anthropogenic emissions is also subject to uncertainty associated with defining accurate activity rates and emission factors for a large number of source activities (EEA, 2013). The UK National Atmospheric Emissions Inventory (NAEI) calculated the uncertainty in UK anthropogenic VOC emissions to be $\pm 10 \%$ (Misra et al., 2015). Of the $62.5 \%$ of UK anthropogenic VOC emissions not emitted as one of the VOCs measured at the supersites, only the additional measurement of ethanol (13\% of 2011 anthropogenic UK emissions), methanol (4\%) and acetone (3\%) would substantially increase the proportion of the UK VOC suite for which VOC diurnal photochemical depletion would be quantified. The measurement of these three VOCs would increase the proportion of UK anthropogenic emissions emitted as a measured VOC from 37.5 to $57.5 \%$. Currently, ethanol, methanol and acetone constitute $35 \%$ of the unmeasured fraction of UK anthropogenic emissions. Contributions from the 40 unmeasured VOCs with the next highest emissions are required to make up the same percentage and the remaining unmeasured emissions fraction comprises 464 VOCs. The large number of VOCs contributing to the "unmeasured" VOC emissions fraction supports the argument that the targeting of high VOC-emitting sources would be more beneficial than reductions in individual VOCs from whatever their source(s). The 
large proportion of UK VOC emissions emitted as ethanol, methanol and acetone (mainly from SNAP 6 (solvents), from which 39, 97 and $91 \%$ of UK anthropogenic emissions of ethanol, methanol and acetone derived in 2011, and SNAP 4 (production processes), which contributed $57 \%$ of ethanol emissions) suggests that, like ethene and $m+p$-xylene, they may have a disproportionately high contribution to VOC diurnal photochemical depletion and hence to the magnitude of the regional $\mathrm{O}_{3}$ increment. Measurement of these oxygenated VOCs at the supersites would allow their contribution to be quantified.

Other limitations, in addition to using measurements of a subset of the emitted VOC suite, include use of monthlydiurnal averages. Monthly-diurnal averages were required to use MLE to derive summary statistics and to calculate hemispheric and regional background $\mathrm{O}_{3}$ concentrations. Additionally, it is more appropriate to consider an ensemble of air-mass back trajectories to reduce the random uncertainty associated with their calculation. The integration of air-mass back trajectories and gridded emission inventories therefore also benefitted from use of monthly averages. Hence, the contribution of VOCs to the average increase in regional $\mathrm{O}_{3}$ increment in a given month was evaluated, rather than any short-term episodic regional $\mathrm{O}_{3}$ increment increases.

An additional uncertainty is associated with the gridded emissions inventory itself. The derivation of the inventory requires accurate determination of emission factors and activity rates for a large number of source activities (EEA, 2013). Previous studies show the uncertainty associated with this process. For example, Koohkan et al. (2013) calculated VOC emissions across Europe using inverse modelling by data assimilation of measurements for $15 \mathrm{VOCs}$, and comparison with the EMEP inventory showed an underestimation of emissions of some VOCs and an overestimation of others. Hence, there is a requirement for improvement of emissions inventory derivation. However, this analysis shows that the future reporting of gridded VOC emissions in source sectors more highly disaggregated than currently (e.g. NFR codes) would also facilitate a more precise identification of those VOC sources most important to mitigation strategies and increase the accuracy in calculating emissions of individual VOCs. For example, Derwent et al. (2007b) applied the POCP concept to calculate the contribution of 248 VOC source categories to regional $\mathrm{O}_{3}$ production using a photochemical trajectory model with a near-explicit chemical mechanism which followed a "worst case" 5-day trajectory bringing aged air masses from Europe to a location on the England-Wales border. A UK-derived VOC emissions speciation was derived and applied to total gridded VOC emission estimates across north-west Europe. While the POCP concept provides an effective means of comparison between different source categories, source category POCPs were calculated without accounting for the spatial variation in the contribution of the different source categories to total VOC emissions.
The work presented here highlights the constraints of representing spatial variation of VOC emissions across Europe with 11 highly aggregated SNAP sectors in terms of accurately determining the suite of VOCs impacting atmospheric composition at a site. This results from a fixed contribution of component activities to the aggregated SNAP sector emissions spatially and temporally (see Sect. 3.3.2), although emissions from different SNAP sectors can vary independently of one another. These constraints would be amplified with no disaggregation of gridded VOC emissions and a constant contribution from component activities spatially and temporally to total VOC emissions, i.e. emissions from each aggregated SNAP sector do not vary independently from one another. The effectiveness of the POCP concept in the determination of the strongest $\mathrm{O}_{3}$-influencing VOC emission sources, and hence the most cost effective mitigation strategies, would be substantially improved by the reporting of gridded emissions at NFR sector level. Finally, the future measurement at supersites of VOCs which are distinct markers for source sectors (e.g. NFR codes) could be used to quantify the contribution from different VOC source sectors.

\section{Conclusions}

A methodology has been demonstrated which links the impact of regional $\mathrm{O}_{3}$ increment to $\mathrm{VOC}$ photochemical depletion and spatially gridded anthropogenic VOC emissions. The utility of this methodology, which integrates atmospheric composition measurements $\left(\mathrm{O}_{3}\right.$ and VOCs), meteorological data and gridded emissions inventory, was shown through the derivation of policy-relevant conclusions using measurement data at the two UK EMEP supersites (Harwell and Auchencorth). The regional $\mathrm{O}_{3}$ increment at Harwell in 2010-2012 was substantially larger than at Auchencorth, but substantially smaller than in 1999-2001. Of the 27 measured anthropogenic VOCs, ethene and $m+p$-xylene consistently contributed the most VOC photochemical depletion during regional $\mathrm{O}_{3}$ production at Harwell and therefore reductions in emissions of these VOCs would be most effective in reducing regional $\mathrm{O}_{3}$ production. To reduce VOC diurnal photochemical depletion further, reductions across a larger number of the VOCs would be required. Of these, ethanol, methanol and acetone appear to be the most important, and measurement of these VOCs at the supersites would provide data for targeting future emission reductions. Additionally, more detailed speciated measurement of biogenic VOCs at the supersite, highlighted previously by von Schneidemesser et al. (2011), would also advance our understanding of the relative contribution of anthropogenic vs. biogenic VOCs in determining the regional $\mathrm{O}_{3}$ increment.

Estimates of the integrated anthropogenic VOC emissions along back trajectories arriving at Harwell have decreased substantially between 1999-2001 and 2010-2012, due to decreases in emissions from SNAP source sector 7 (road trans- 
port). Currently, SNAP sector 6 (solvent and product use) provides most of the total VOC trajectory emissions estimate. The disaggregation of highly aggregated SNAP trajectory emission estimates to NFR codes, accounting for country variation in the NFR sector contribution to parent SNAP sector, allowed the source sectors which determine the VOC contribution to the regional $\mathrm{O}_{3}$ impact to be more precisely defined, i.e. NFR sectors 3D2 (domestic solvent use), 3D3 (other product use) and 2D2 (food and drink), which were the top three contributors to total VOC emissions exposure at Harwell (2010-2012) during the month of maximum regional $\mathrm{O}_{3}$ increment. It is concluded that considerable additional benefits to the interpretation of measurement data, to modelling of future $\mathrm{O}_{3}$ concentrations and hence to determining policy for abatement of detrimental $\mathrm{O}_{3}$ impacts would be gained from the availability of gridded VOC emissions data reported in more narrowly defined source sectors such as the NFR codes.

Acknowledgements. C. S. Malley acknowledges the University of Edinburgh School of Chemistry, the NERC Centre for Ecology \& Hydrology (NERC-CEH studentship funding project no. NEC04544) and the UK Department for Environment, Food and Rural Affairs (Defra grant no. AQ0647) for funding. Defra contractors Ricardo-AEA, Bureau Veritas and NERC Centre for Ecology \& Hydrology and their field teams are acknowledged for operating the UK EMEP supersites.

Edited by: M. Shao

\section{References}

Akaike, H.: New look at statistical-model identification, IEEE T. Automat. Contr., 19, 716-723, 1974.

Atkinson, R.: Atmospheric chemistry of VOCs and $\mathrm{NO}_{x}$, Atmos. Environ., 34, 2063-2101, 2000.

Atkinson, R. and Arey, J.: Atmospheric degradation of volatile organic compounds, Chem. Rev., 103, 4605-4638, 2003.

Borbon, A., Gilman, J. B., Kuster, W. C., Grand, N., Chevaillier, S., Colomb, A., Dolgorouky, C., Gros, V., Lopez, M., Sarda-Esteve, R., Holloway, J., Stutz, J., Petetin, H., McKeen, S., Beekmann, M., Warneke, C., Parrish, D. D., and de Gouw, J. A.: Emission ratios of anthropogenic volatile organic compounds in northern mid-latitude megacities: Observations versus emission inventories in Los Angeles and Paris, J. Geophys. Res-Atmos., 118, 2041-2057, doi:10.1002/jgrd.50059, 2013.

Bowman, F. M.: A multi-parent assignment method for analyzing atmospheric chemistry mechanisms, Atmos. Environ., 39, 25192533, 2005.

Butler, T. M., Lawrence, M. G., Taraborrelli, D., and Lelieveld, J.: Multi-day ozone production potential of volatile organic compounds calculated with a tagging approach, Atmos. Environ., 45, 4082-4090, 2011.

Carslaw, D. C. and Ropkins, K.: openair - An R package for air quality data analysis, Environ. Modell. Softw., 27-28, 52-61, doi:10.1016/j.envsoft.2011.09.008, 2012.
Clapp, L. J. and Jenkin, M. E.: Analysis of the relationship between ambient levels $\mathrm{Of}_{3}, \mathrm{NO}_{2}$ and $\mathrm{NO}$ as a function of $\mathrm{NO}_{X}$ in the UK, Atmos. Environ., 35, 6391-6405, 2001.

Dernie, J. and Dumitrean, P.: UK Hydrocarbon Network: Annual Report for 2012, Report No. ED47833 and ED46645 for Defra and the Devolved Administrations, Ricardo-AEA, http://uk-air.defra.gov.uk/assets/documents/reports/cat13/

1311201446_Hydrocarbon_2012_FINAL_Issue_1.pdf (last access: 23 July 2015), 2013.

Derwent, R. G., Jenkin, M. E., Passant, N. R., and Pilling, M. J.: Reactivity-based strategies for photochemical ozone control in Europe, Environ. Sci. Policy, 10, 445-453, 2007a.

Derwent, R. G., Jenkin, M. E., Passant, N. R., and Pilling, M. J.: Photochemical ozone creation potentials (POCPs) for different emission sources of organic compounds under European conditions estimated with a Master Chemical Mechanism, Atmos. Environ., 41, 2570-2579, 2007b.

Derwent, R. G., Simmonds, P. G., Manning, A. J., and Spain, T. G.: Trends over a 20-year period from 1987 to 2007 in surface ozone at the atmospheric research station, Mace Head, Ireland, Atmos. Environ., 41, 9091-9098, 2007c.

Derwent, R. G., Jenkin, M. E., Pilling, M. J., Carter, W. P. L., and Kaduwela, A.: Reactivity Scales as Comparative Tools for Chemical Mechanisms, J. Air Waste Manage., 60, 914-924, 2010.

Derwent, R. G., Dernie, J. I. R., Dollard, G. J., Dumitrean, P., Mitchell, R. F., Murrells, T. P., Telling, S. P., and Field, R. A.: Twenty years of continuous high time resolution volatile organic compound monitoring in the United Kingdom from 1993 to 2012, Atmos. Environ., 99, 239-247, 2014.

Dollard, G. J., Dumitrean, P., Telling, S., Dixon, J., and Derwent, R. G.: Observed trends in ambient concentrations of $\mathrm{C}_{2}-\mathrm{C}_{8}$ hydrocarbons in the United Kingdom over the period from 1993 to 2004, Atmos. Environ., 41, 2559-2569, 2007.

Draxler, R. R. and Rolph, G. D.: HYSPLIT (HYbrid Single-Particle Lagrangian Integrated Trajectory) Model, NOAA ARL READY Website, available at: http://www.arl.noaa.gov/HYSPLIT.php (last access: 23 July 2015), NOAA Air Resources Laboratory, College Park, MD, 2013.

EEA: EMEP/EEA air pollutant emission inventory guidebook 2013, EEA technical report No. 12/2013, European Environment Agency, available at: http://www.eea.europa.eu/publications/ emep-eea-guidebook-2013 (last access: 23 July 2015), 2013.

EEA: EU emission inventory report 1990-2012 under the UNECE Convention on long-range transboundary air pollution (LRTAP), EEA technical report No. 12/2014, European Environment Agency, available at: http://www.eea.europa.eu//publications/ lrtap-2014 (last access: 23 July 2015), 2014.

Gardner, M.: Improving the interpretation of 'less than' values in environmental monitoring, Water Environ. J., 26, 285-290, 2012.

Gauss, M., Semeena, V., Benedictow, A., and Klein, H.: Transboundary air pollution by main pollutants ( $\mathrm{S}, \mathrm{N}$, Ozone) and PM: The European Union, MSC-W Data Note 1/2014, available at: http://emep.int/publ/reports/2014/Country_Reports/ report_EU.pdf (last access: 23 July 2015), 2014.

Hakami, A., Harley, R. A., Milford, J. B., Odman, M. T., and Russell, A. G.: Regional, three-dimensional assessment of the ozone formation potential of organic compounds, Atmos. Environ., 38, 121-134, 2004. 
Helmig, D., Tanner, D. M., Honrath, R. E., Owen, R. C., and Parrish, D. D.: Nonmethane hydrocarbons at Pico Mountain, Azores: 1. Oxidation chemistry in the North Atlantic region, J. Geophys. Res., 113, D20S91, doi:10.1029/2007jd008930, 2008.

Helsel, D. R.: Fabricating data: How substituting values for nondetects can ruin results, and what can be done about it, Chemosphere, 65, 2434-2439, 2006.

Honrath, R. E., Helmig, D., Owen, R. C., Parrish, D. D., and Tanner, D. M.: Nonmethane hydrocarbons at Pico Mountain, Azores: 2. Event-specific analyses of the impacts of mixing and photochemistry on hydrocarbon ratios, J. Geophysical Res., 113, D20S92, 10.1029/2008jd009832, 2008.

Jenkin, M. E.: Trends in ozone concentration distributions in the UK since 1990: Local, regional and global influences, Atmos. Environ., 42, 5434-5445, 2008.

Jenkin, M. E. and Clemitshaw, K. C.: Ozone and other secondary photochemical pollutants: chemical processes governing their formation in the planetary boundary layer, Atmos. Environ., 34, 2499-2527, 2000.

Jobson, B. T., McKeen, S. A., Parrish, D. D., Fehsenfeld, F. C., Blake, D. R., Goldstein, A. H., Schauffler, S. M., and Elkins, J. C.: Trace gas mixing ratio variability versus lifetime in the troposphere and stratosphere: Observations, J. Geophys. Res., 104, 16091-16113, doi:10.1029/1999jd900126, 1999.

Karl, M., Guenther, A., Köble, R., Leip, A., and Seufert, G.: A new European plant-specific emission inventory of biogenic volatile organic compounds for use in atmospheric transport models, Biogeosciences, 6, 1059-1087, doi:10.5194/bg-6-1059-2009, 2009.

Kaufman, L. and Rousseeuw, P. J.: Finding Groups in Data: An Introduction to ClusterAnalysis, Wiley, New York, 1990.

Koohkan, M. R., Bocquet, M., Roustan, Y., Kim, Y., and Seigneur, C.: Estimation of volatile organic compound emissions for Europe using data assimilation, Atmos. Chem. Phys., 13, 58875905, doi:10.5194/acp-13-5887-2013, 2013.

Lanz, V. A., Henne, S., Staehelin, J., Hueglin, C., Vollmer, M. K., Steinbacher, M., Buchmann, B., and Reimann, S.: Statistical analysis of anthropogenic non-methane VOC variability at a European background location (Jungfraujoch, Switzerland), Atmos. Chem. Phys., 9, 3445-3459, doi:10.5194/acp-9-3445-2009, 2009

Laurent, A. and Hauschild, M. Z.: Impacts of NMVOC emissions on human health in European countries for 2000-2010: Use of sector-specific substance profiles, Atmos. Environ., 85, 247-255, 2014.

Luecken, D. J. and Mebust, M. R.: Technical challenges involved in implementation of VOC reactivity-based control of ozone, Environ. Sci. Technol., 42, 1615-1622, 2008.

Malley, C. S., Braban, C. F., and Heal, M. R.: New Directions: Chemical climatology and assessment of atmospheric composition impacts., Atmos. Environ., 87, 261-264, 2014a.

Malley, C. S., Braban, C. F., and Heal, M. R.: The application of hierarchical cluster analysis and non-negative matrix factorization to European atmospheric monitoring site classification., Atmos. Res., 138, 30-40, 2014b.

Malley, C. S., Heal, M. R., Mills, G., and Braban, C. F.: Trends and drivers of ozone human health and vegetation impact metrics from UK EMEP supersite measurements (1990-2013), Atmos. Chem. Phys., 15, 4025-4042, doi:10.5194/acp-15-4025$2015,2015$.
Mangiameli, P., Chen, S. K., and West, D.: A comparison of SOM neural network and hierarchical clustering methods, Eur. J. Oper. Res., 93, 402-417, 1996.

Mareckova, K., Wankmueller, R., Whiting, R., and Pinterits, M.: Review of emission data reported under the LRTAP Convention and NEC Directive, Stage 1 and 2 review, Review of emission inventories from shipping, Status of Gridded and LPS data, EEA and CEIP technical report, 1/2013, available at: http://www. ceip.at/review-of-inventories/review-2013/ (last access: 23 July 2015), 2013.

Martien, P. T., Harley, R. A., Milford, J. B., and Russell, A. G.: Evaluation of incremental reactivity and its uncertainty in Southern California, Environ. Sci. Technol., 37, 1598-1608, 2003.

Misra, A., Passant, N. R., Murrells, T. P., Pang, Y., Thistlethwaite, G., Walker, C., Broomfield, M., Wakeling, D., del Vento, S., Pearson, B., Hobson, M., Misselbrook, T., and Dragosits, U.: UK Informative Inventory Report (1990 to 2013): Annual Report for Submission under the UNECEConvention on Long-Range Transboundary Air Pollution, available at: http://uk-air.defra.gov.uk/assets/documents/reports/ cat07/1503131022_GB_IIR_2015_Final_v20.pdf (last access: 23 July 2015), 2015.

Munir, S., Chen, H., and Ropkins, K.: Quantifying temporal trends in ground level ozone concentration in the UK, Sci. Total Environ., 458, 217-227, 2013.

Oderbolz, D. C., Aksoyoglu, S., Keller, J., Barmpadimos, I., Steinbrecher, R., Skjøth, C. A., Plaß-Dülmer, C., and Prévôt, A. S H.: A comprehensive emission inventory of biogenic volatile organic compounds in Europe: improved seasonality and landcover, Atmos. Chem. Phys., 13, 1689-1712, doi:10.5194/acp-131689-2013, 2013.

Passant, N. R.: Speciation of UK emissions of non-methane volatile organic compounds. AEA Technology Report ENV-0545, Culham, Abingdon, UK, available at: http://uk-air.defra.gov.uk/ reports/empire/AEAT_ENV_0545_final_v2.pdf (last access: 23 July 2015), 2002.

Passant, N. R., Murrells, T. P., Pang, Y., Thistlewaite, G., Venfield, H. L., Whiting, R., Walker, C., MacCarthy, J., Watterson, J., Hobson, M., and Misselbrook, T.: UK Informative Inventory Report (1980 to 2011), available at: http://uk-air.defra.gov. uk/reports/cat07/1303261254_UK_IIR_2013_Final.pdf (last access: 23 July 2015), 2013.

Perry, M. and Hollis, D.: The development of a new set of long-term climate averages for the UK, Int. J. Climatol., 25, 1023-1039, doi:10.1002/joc.1160, 2005.

R Core Development Team: R: A language and environment for statistical computing. R Foundation for Statistical Computing, Vienna, Austria, available at: http://www.R-project.org (last access: 23 July 2015), 2008.

REVIHAAP: Review of evidence on health aspects of air pollution - REVIHAAP Project technical report, World Health Organization (WHO) Regional Office for Europe, Bonn, available at: http://www.euro.who.int/_data/assets/pdf_file/0004/193108/ REVIHAAP-Final-technical-report-final-version.pdf (last access: 23 July 2015), 2013.

RoTAP: Review of Transboundary Air pollution: Acidification, Eutrophication, Ground Level Ozone and Heavy metals in the UK. Contract Report to the Department for Environment, Food 
and Rural Affairs, Centre for Ecology and Hydrology, available at: http://www.rotap.ceh.ac.uk/ (last access: 23 July 2015), 2012.

Sauvage, S., Plaisance, H., Locoge, N., Wroblewski, A., Coddeville, P., and Galloo, J. C.: Long term measurement and source apportionment of non-methane hydrocarbons in three French rural areas, Atmos. Environ., 43, 2430-2441, 2009.

Shao, M., Lu, S., Liu, Y., Xie, X., Chang, C., Huang, S., and Chen, Z.: Volatile organic compounds measured in summer in Beijing and their role in ground-level ozone formation, J. Geophys. Res., 114, D00G06, doi:10.1029/2008jd010863, 2009.

Simpson, D., Benedictow, A., Berge, H., Bergström, R., Emberson, L. D., Fagerli, H., Flechard, C. R., Hayman, G. D., Gauss, M., Jonson, J. E., Jenkin, M. E., Nyíri, A., Richter, C., Semeena, V. S., Tsyro, S., Tuovinen, J.-P., Valdebenito, Á., and Wind, P.: The EMEP MSC-W chemical transport model - technical description, Atmos. Chem. Phys., 12, 7825-7865, doi:10.5194/acp-127825-2012, 2012.

Tarasova, O. A., Brenninkmeijer, C. A. M., Jöckel, P., Zvyagintsev, A. M., and Kuznetsov, G. I.: A climatology of surface ozone in the extra tropics: cluster analysis of observations and model results, Atmos. Chem. Phys., 7, 6099-6117, doi:10.5194/acp-76099-2007, 2007.
Tørseth, K., Aas, W., Breivik, K., Fjæraa, A. M., Fiebig, M., Hjellbrekke, A. G., Lund Myhre, C., Solberg, S., and Yttri, K. E.: Introduction to the European Monitoring and Evaluation Programme (EMEP) and observed atmospheric composition change during 1972-2009, Atmos. Chem. Phys., 12, 5447-5481, doi:10.5194/acp-12-5447-2012, 2012.

von Schneidemesser, E., Monks, P. S., and Plass-Duelmer, C.: Global comparison of VOC and CO observations in urban areas, Atmos. Environ., 44, 5053-5064, 2010.

von Schneidemesser, E., Monks, P. S., Gros, V., Gauduin, J., and Sanchez, O.: How important is biogenic isoprene in an urban environment? A study in London and Paris, Geophys. Res. Lett., 38, L19804, doi:10.1029/2011g1048647, 2011.

Yates, E. L., Derwent, R. G., Simmonds, P. G., Greally, B. R., O'Doherty, S., and Shallcross, D. E.: The seasonal cycles and photochemistry of $\mathrm{C}_{2}-\mathrm{C}_{5}$ alkanes at Mace Head, Atmos. Environ., 44, 2705-2713, 2010.

Yuan, B., Shao, M., de Gouw, J., Parrish, D. D., Lu, S., Wang, M., Zeng, L., Zhang, Q., Song, Y., Zhang, J., and Hu, M.: Volatile organic compounds (VOCs) in urban air: How chemistry affects the interpretation of positive matrix factorization (PMF) analysis, J. Geophys. Res., 117, D24302, doi:10.1029/2012jd018236, 2012. 